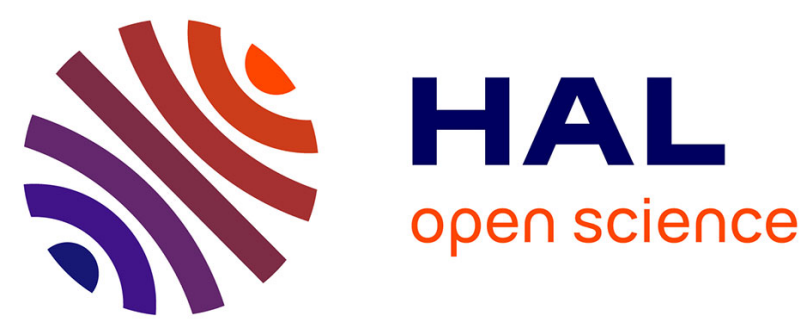

\title{
From the Surface Structure to Catalytic Properties of Al 5 Co 2 (210): A Study Combining Experimental and Theoretical Approaches
}

Corentin Chatelier, Yves Garreau, Laurent Piccolo, Alina Vlad, Andrea Resta, Julian Ledieu, Vincent Fournée, Marie-Cécile De Weerd, Frédéric-Emmanuel Picca, Marc De Boissieu, et al.

\section{To cite this version:}

Corentin Chatelier, Yves Garreau, Laurent Piccolo, Alina Vlad, Andrea Resta, et al.. From the Surface Structure to Catalytic Properties of Al 5 Co 2 (210): A Study Combining Experimental and Theoretical Approaches. Journal of Physical Chemistry C, 2020, 10.1021/acs.jpcc.9b09675 . hal-02478625

\section{HAL Id: hal-02478625 \\ https://hal.science/hal-02478625}

Submitted on 11 Sep 2020

HAL is a multi-disciplinary open access archive for the deposit and dissemination of scientific research documents, whether they are published or not. The documents may come from teaching and research institutions in France or abroad, or from public or private research centers.
L'archive ouverte pluridisciplinaire HAL, est destinée au dépôt et à la diffusion de documents scientifiques de niveau recherche, publiés ou non, émanant des établissements d'enseignement et de recherche français ou étrangers, des laboratoires publics ou privés. 


\title{
From Surface Structure to Catalytic Properties of $\mathrm{Al}_{5} \mathrm{Co}_{2}(2 \overline{10})$ : a Study Combining Experimental and Theoretical Approaches
}

\author{
Corentin Chatelier ${ }^{1,2}$, Yves Garreau ${ }^{2,3}$, Laurent Piccolo ${ }^{4}$, Alina Vlad ${ }^{2}$, Andrea Resta ${ }^{2}$, Julian \\ Ledieu $^{1}$, Vincent Fournée ${ }^{1}$, Marie-Cécile de Weerd ${ }^{1}$, Frédéric-Emmanuel Picca ${ }^{2}$, \\ Marc de Boissieu ${ }^{5}$, Roberto Felici ${ }^{6}$, Alessandro Coati*,2 and Émilie Gaudry*,1 \\ * \\ ${ }^{1}$ Université de Lorraine, CNRS, Institut Jean Lamour - UMR 7198, Campus ARTEM, 2 Allée André Guinier, F-54011, Nancy, \\ France \\ ${ }^{2}$ Synchrotron SOLEIL, L'Orme des Merisiers, Saint-Aubin, BP 48, F-91192 Gif-sur-Yvette Cedex, France \\ ${ }^{3}$ Université de Paris, Laboratoire Matériaux et Phénomènes Quantiques, CNRS, F-75013, Paris, France \\ ${ }^{4}$ Univ Lyon, Université Claude Bernard - Lyon 1, CNRS, IRCELYON - UMR 5256, 2 Avenue Albert Einstein, F-69626, \\ Villeurbanne CEDEX, France \\ ${ }^{5}$ Université Grenoble Alpes, CNRS, Science et Ingénierie des Matériaux et Procédés - UMR 5266,1130 rue de la piscine, \\ Domaine Universitaire, BP 75, F-38402 Saint-Martin d'Hères, France \\ ${ }^{6}$ CNR-SPIN, Area della Ricerca di Tor Vergata, Via del Fosso del Cavaliere 100, I-00133 Roma, Italy \\ E-mail: alessandro.coati@synchrotron-soleil.fr,emilie.gaudry@univ-lorraine.fr
}

\begin{abstract}
Replacing noble metal catalysts with inexpensive, environmentally harmless, active, selective and stable substitutes, is a great challenge for the chemical industry. In this paper, the noble metal-free $\mathrm{Al}_{5} \mathrm{Co}_{2}(2 \overline{1} 0)$ complex intermetallic surface is experimentally identified as active and selective for the semi-hydrogenation of butadiene. The catalyst surface structure and chemical composition are determined by experimental techniques - surface X-ray diffraction (SXRD), scanning tunneling microscopy (STM) - combined with ab initio calculations. Theoretical investigations of the adsorption properties under reaction conditions demonstrate that the surface Co atomic density drastically impacts the thermodynamic feasibility of the hydrogenation reaction, and they provide information on the reaction mechanism. This work offers insights for the rational design of Al-based catalysts for hydrocarbon hydrogenation reactions.
\end{abstract}

\section{Introduction}

Catalysis plays a large role in today's chemical industry and there is a constant demand for better and cheaper catalysts. In this regard, the selective hydrogenation of alkynes and dienes from streams containing alkenes are important class of reactions in the petrochemical industry. Steam cracking, catalytic cracking and coking lead to traces of alkynes and/or dienes, which have to be selectively hydrogenated into olefinic compounds before alkenes can be further processed by polymerization or selective oxidation. In this context, the development of catalysts with a high activity, stability and selectivity is crucial.

Noble metal Pd-based catalysts are typical ones for the alkynes and dienes hydrogenations. The reaction selectivities to partially hydrogenated products can be improved by the addition of an inactive coinage metal such as $\mathrm{Ag}$, $\mathrm{Au}$ or $\mathrm{Cu} .{ }^{1-4}$ First-principles calculations suggested $\mathrm{Ni}-\mathrm{Zn}$ alloys as low-cost substitutes to reference $\mathrm{Pd}-\mathrm{Ag}^{5}$ for acetylene partial hydrogenation. These substitutional alloys may nevertheless suffer from adsorption-induced surface segregation under reaction conditions, which usually leads to a decrease in selec- tivity. ${ }^{2,6,7}$

Searching for stable, selective, low-cost and environmentally benign catalysts for acetylene and butadiene semi-hydrogenations led to the recent identification of transition-metal (TM) Al-based quasicrystalline approximants such as $\mathrm{Al}_{13} \mathrm{Fe}_{4}, \mathrm{Al}_{13} \mathrm{Co}_{4}$, and $\mathrm{Al}_{13} \mathrm{Ru}_{4} \cdot{ }^{8-15} \mathrm{~A}$ great asset of these compounds is related to their covalent-like chemical bonding network, that may prevent any surface segregation process, ensuring the structural stability of the catalyst. ${ }^{16,17}$ The room temperature activity towards the gas-phase butadiene hydrogenation was shown to increase in the order $o-\mathrm{Al}_{13} \mathrm{Co}_{4}(100) \ll m-\mathrm{Al}_{13} \mathrm{Ru}_{4}(010)<m-\mathrm{Al}_{13} \mathrm{Fe}_{4}(010)$, when comparing the same types of pseudo 10-fold surfaces. ${ }^{15}$

Several factors may influence the catalytic performances of intermetallic compounds. ${ }^{18}$ Isolating active transition metal atoms into single-sites through alloying generally increases the selectivity. ${ }^{19,20}$ In the case of pure metals, the adsorption properties of the reactants and therefore the reaction barriers can be rationalized by their electronic structure (d-band position and width). ${ }^{21,22}$ Correlations between electronic structure and selectivity also exist in the case of intermetallic 
compounds. ${ }^{23,24}$ Last, surface corrugation plays a role. For exemple, mono-atomic steps may offer completely new reaction pathways with highly reduced energy barriers compared to flat surfaces. ${ }^{25}$

Looking for other Al-based quasicrystalline approximants presenting structural and electronic similarities with the $\mathrm{Al}_{13} \mathrm{TM}_{4}$ pseudo 10-fold surfaces leads to the consideration of $\mathrm{Al}_{5} \mathrm{Co}_{2}(2 \overline{1} 0)$. This surface is highly corrugated, due to the absence of selected bi-pentagonal Al motifs at the surface as highlighted in ref. ${ }^{26}$ by combining first principles calculations and surface science techniques (Low Energy Electron Diffraction - LEED, and Scanning Tunneling Microscopy - STM). Surface Co atoms are isolated, embedded in $\mathrm{Al}$ pentagonal arrangements and the d-band is localized around $-2.0 \mathrm{eV}$, like the one for bulk $o-\mathrm{Al}_{13} \mathrm{Co}_{4}\left(-1.97 \mathrm{eV}^{15}\right)$.

The promising catalytic performances of $\mathrm{Al}_{5} \mathrm{Co}_{2}(2 \overline{1} 0)$ were suggested by a recent theoretical investigation. ${ }^{27}$ This study highlighted the influence of the topmost surface Co atoms on the adsorption properties and catalytic activity, in the case of the semi-hydrogenation of acetylene. Depending on the surface atomic composition, the acetylene adsorption site - a 4-fold hollow site - is surrounded by $2 \mathrm{Al}$ and $2 \mathrm{Co}$ atoms $\left(E_{a d s}=-261\right.$ $\left.\mathrm{kJ} . \mathrm{mol}^{-1}\right)$ or $4 \mathrm{Al}$ atoms $\left(E_{a d s}=-233 \mathrm{~kJ} . \mathrm{mol}^{-1}\right)$. The presence/ absence of surface Co atoms is shown to impact the reaction path and barriers, with an activation energy of the rate-controlling step lower for Co-rich surfaces $\left(60 \mathrm{~kJ} \mathrm{~mol}{ }^{-1}\right)$ compared to Al-rich surfaces (80 $\left.\mathrm{kJ} . \mathrm{mol}^{-1}\right)$. However, up to now, no experimental work addressed the catalytic properties of $\mathrm{Al}_{5} \mathrm{Co}_{2}(2 \overline{1} 0)$.

The previous theoretical results highlighted that the detailed knowledge of the $\mathrm{Al}_{5} \mathrm{Co}_{2}(2 \overline{1} 0)$ surface structure and composition is required to get a deep understanding of its catalytic properties. Our previous study showed that $\mathrm{Al}_{5} \mathrm{Co}_{2}(2 \overline{1} 0)$ presents an unique termination with no significant surface segregation. A $(2 \times 1)$ surface reconstruction was observed by LEED and STM with 12 $\AA$-wide strips running parallel to the $c$ axis. Calculations based on the Density Functional Theory (DFT) identified two structural models with low surface energies and compatible with the experimental observations. However, the comparison between experimental and simulated STM images alone does not allow any discrimination between these two models, which differ by the number of protruding surface Co atoms.

Here, a thorough study of the catalytic performances of $\mathrm{Al}_{5} \mathrm{Co}_{2}(2 \overline{1} 0)$ for butadiene hydrogenation is reported. It combines experimental catalytic measurements, a detailed determination of the surface structure and chemical composition, thanks to $a b$ initio surface calculations combined with STM and surface X-ray diffraction (SXRD), a powerful tool for the determination of complex intermetallic surface structures, as already demonstrated. ${ }^{28,29}$ The surface chemical composition (surface Co atomic density) is shown to drastically influence the adsorption and co-adsorption properties, which impact the thermodynamic feasibility of the hydrogenation reaction.

\section{Methods}

\section{Experimental details}

Surface preparation : The experiments were performed using our $\mathrm{Al}_{5} \mathrm{Co}_{2}$ single crystal cut parallel to the $(2 \overline{1} 0)$ planes. The sample was extracted from an ingot, grown from an Al-rich solution by the Czochralski method (see ref. ${ }^{30}$ for details) and oriented using backscattered X-ray Laue technique, polished down to 0.25 $\mu \mathrm{m}$ using a diamond paste and mounted on a Ta plate. $\mathrm{Al}_{5} \mathrm{Co}_{2}(2 \overline{1} 0)$ was prepared by cycles of $30 \mathrm{~min} 2 \mathrm{keV}$ $\mathrm{Ar}^{+}$sputtering followed by 1 hour annealing at $973 \mathrm{~K}$ in UHV. A $(2 \times 1)$ surface reconstruction was observed by LEED (Fig. S1), as previously reported. ${ }^{26}$ Neither oxygen, nor carbon surface contaminations were observed by Auger Electron Spectroscopy (AES, Fig. S2).

Catalytic measurements : The reaction was performed in a dedicated static catalytic reactor coupled with UHV preparation and analysis chambers (LEED and AES). ${ }^{31}$ The sample was heated from the back by an infrared laser beam. The surface temperature was controlled using an infrared pyrometer (surface emissivity set to 0.3 ). A mixture of ultra pure gases (5 mbar hydrogen, 0.5 mbar butadiene and 0.5 mbar Ar for internal calibration) was prepared in a separate chamber before injection into the reactor. The reactants and products were monitored by mass spectroscopy and gas chromatography.

Surface X-ray diffraction : Surface diffraction measurements were performed at the Surfaces and Interfaces X-ray Scattering (SixS) beamline at SOLEIL Synchrotron. In SixS' setup, a UHV (low $10^{-10} \mathrm{mbar}$ ) preparation chamber (LEED, AES) is connected to a UHV measurement chamber, mounted on a Z-axis diffractometer ${ }^{32,33}$ allowing the transfer of the sample into the diffraction chamber. SXRD measurements were carried out at an energy of $18.41 \mathrm{keV}$ and an incident angle of $\mu=0.3^{\circ}$. A $2 \mathrm{D}$ hybrid pixel detector (XPAD S140) was used to collect the scattered intensities ${ }^{34}$ and BINoculars program was used to process the whole data set. ${ }^{35}$

AVE and ROD softwares (from the ANAROD suite ${ }^{36}$ ) were used to analyze the processed data generated by BINoculars. Several crystal truncation rods (CTRs) and super-structure rods (SSRs) were measured. Structure factors of CTRs and SSRs were simulated from - in our case - DFT-relaxed surface models. The adequacy of the simulated CTRs and SSRs intensities with the experimental data is quantified by the $\chi^{2}$ factor

$$
\chi^{2}=\frac{1}{N_{d a t a}-N_{p}} \sum\left|\frac{I_{e x p}-I_{t h}}{\sigma}\right|^{2}
$$

where $N_{\text {data }}$ is the number of data points, $I_{\exp }$ (resp. $\left.I_{t h}\right)$ the experimental intensity (resp. simulated inten- 
sity), $N_{p}$ the number of refined parameters and $\sigma$ the estimated error bars. In our case, only one parameter - the scale factor - is refined $\left(N_{p}=1\right)$. Miller indices will further be referred to $\mathrm{H}, \mathrm{K}$ and $\mathrm{L}$. They are given with respect to the $(2 \times 1)$ surface reconstruction and not with respect to the $(1 \mathrm{x} 1)$ substrate unit cell.

\section{Theoretical methods based on DFT}

Computational details : DFT calculations were performed using the Vienna ab initio simulation package (VASP). ${ }^{37-40}$ The interaction between the valence electrons and the ionic core was described using the projector-augmented wave (PAW) method ${ }^{41,42}$ within the generalized gradient approximation (GGAPBE) ${ }^{43,44}$ considering the valences for the atoms to be $3 s^{2} 3 p^{1}(\mathrm{Al}), 4 s^{1} 3 d^{8}(\mathrm{Co}), 2 s^{2} 2 p^{2}(\mathrm{C})$ and $1 s^{1}(\mathrm{H})$. Spin polarization was not taken into account, as it was shown to be unnecessary for such Al-rich complex intermetallic compounds. ${ }^{45,46}$ Total energies were minimized until the energy differences become less than $10^{-6} \mathrm{eV}$ between two electronic cycles during the structural optimizations. Atomic structures were relaxed untill the Hellmann-Feynman forces were as low as $0.02 \mathrm{eV}$. The structural models were plotted using the VESTA software. $^{47}$

Total energy calculations were performed using a cutoff energy $\left(\mathrm{E}_{c u t}\right)$ and a number of $k$-points within the Brillouin zone such as to achieve an energy accuracy better than $0.1 \mathrm{meV} /$ at. $\left(\mathrm{E}_{\text {cut }}=450 \mathrm{eV}\right.$, MonkhorstPack $k$-points grid $=8 \times 8 \times 8$ for bulk calculations, $2 \times 8 \times 1$ for surface calculations). The consideration of dispersion corrections is recommended to evaluate adsorption energies of extended molecules on metallic surfaces. Here, we have chosen the DFT-D3 scheme, ${ }^{48}$ which is considered as a valuable approach for the treatment of large systems. ${ }^{49}$

Using this set-up, the computed cell parameters for face-centered cubic $\mathrm{Al}\left(a_{\mathrm{DFT}}^{\mathrm{Al}}=4.01 \AA\right)$ and hexagonal close packed Co $\left(a_{\mathrm{DFT}}^{\mathrm{Co}}=2.47 \AA, c_{\mathrm{DFT}}^{\mathrm{Co}}=3.99 \AA\right)$ are in reasonable agreement with the experimental data $\left(a_{e x p}^{\mathrm{Al}}=4.05 \AA ;{ }^{50} a_{e x p}^{\mathrm{Co}}=2.51 \AA, c_{e x p}^{\mathrm{Co}}=4.07 \AA^{51}\right)$. These parameters also lead to a fairly good agreement of theoretical cohesive energies $\left(E_{\mathrm{DFT}}^{\text {coh }}(\mathrm{Al})=-3.67\right.$ $\mathrm{eV} /$ atom, $E_{\mathrm{DFT}}^{c o h}(\mathrm{Co})=-5.50 \mathrm{eV} /$ atom $)$ with experimental ones $\left(E_{\exp }^{c o h}(\mathrm{Al})=-3.39 \mathrm{eV} /\right.$ atom, $E_{\exp }^{\text {coh }}(\mathrm{Co})=$ $-5.44 \mathrm{eV} /$ atom $\left.^{52}\right)$. The same conclusions can be drawn for the $\mathrm{Al}_{5} \mathrm{Co}_{2}$ compound (Tab. 1).

Surface energy calculations were realized using 13layer thick $(21.5 \AA)$ symmetric slabs, separated by a $20 \AA$ thick void (see Section S2 for details). STM image simulations were performed using the Tersoff-Hamann approximation. ${ }^{55,56}$ Asymmetric 6-layer thick slabs (3 fixed atomic planes and 3 atomic planes allowed to relax) were used for the investigation of the adsorption properties. All calculations were done with a $\mathrm{C}_{4} \mathrm{H}_{6}$ or $\mathrm{C}_{4} \mathrm{H}_{8}$ coverage not greater than one alkene molecule per surface cell $(a=26.58 \AA, \mathrm{b}=7.60 \AA)$.
Table 1: Theoretical crystallographic and thermodynamic data for bulk $\mathrm{Al}_{5} \mathrm{Co}_{2}$ : cell parameters with relative errors, atomic positions in fractional coordinates and formation enthalpy calculated using $7 \Delta H_{f}=E_{\mathrm{DFT}}^{c o h}\left(\mathrm{Al}_{5} \mathrm{Co}_{2}\right)-$ $5 E_{\mathrm{DFT}}^{c o h}(\mathrm{Al})-2 E_{\mathrm{DFT}}^{c o h}(\mathrm{Co})$.

\begin{tabular}{|c|c|c|c|c|}
\hline \multicolumn{5}{|c|}{ Crystal cell } \\
\hline $\begin{array}{l}a(\AA) \\
c(\AA)\end{array}$ & $\begin{array}{c}\text { this work } \\
7.60 \\
7.52\end{array}$ & $\begin{array}{c}\text { Exp. }^{53} \\
7.67 \\
7.61\end{array}$ & $\begin{array}{c}\text { Rel. Error } \\
0.9 \% \\
1.2 \%\end{array}$ & \\
\hline \multicolumn{5}{|c|}{ Wyckoff positions $(\mathrm{x}, \mathrm{y}, \mathrm{z})$} \\
\hline $\mathrm{Al}_{1}(2 a)$ & $\begin{array}{l}\text { this work } \\
\text { Exp. }^{53}\end{array}$ & $\begin{array}{l}0 \\
0\end{array}$ & $\begin{array}{l}0 \\
0\end{array}$ & $\begin{array}{l}0 \\
0\end{array}$ \\
\hline $\mathrm{Al}_{2}(6 h)$ & $\begin{array}{l}\text { this work } \\
\text { Exp. }^{53}\end{array}$ & $\begin{array}{l}0.4672 \\
0.4645\end{array}$ & $\begin{array}{l}0.9344 \\
0.9290\end{array}$ & $\begin{array}{l}\frac{1}{4} \\
\frac{1}{4}\end{array}$ \\
\hline $\mathrm{Al}_{3}(12 k)$ & $\begin{array}{l}\text { this work } \\
\text { Exp. }^{53}\end{array}$ & $\begin{array}{l}0.1948 \\
0.1944\end{array}$ & $\begin{array}{l}0.3896 \\
0.3888\end{array}$ & $\begin{array}{l}4 \\
0.9409 \\
0.9386\end{array}$ \\
\hline $\mathrm{Co}_{1}(2 d)$ & $\begin{array}{l}\text { this work } \\
\text { Exp. }{ }^{53}\end{array}$ & $\begin{array}{l}\frac{1}{3} \\
\frac{1}{3}\end{array}$ & $\frac{2}{3}$ & $\begin{array}{l}\frac{3}{4} \\
\frac{3}{4}\end{array}$ \\
\hline $\mathrm{Co}_{2}(6 h)$ & $\begin{array}{l}\text { this work } \\
\text { Exp. }^{53}\end{array}$ & $\begin{array}{l}0.1270 \\
0.1274\end{array}$ & $\begin{array}{l}0.2539 \\
0.2548\end{array}$ & $\begin{array}{l}\frac{1}{4} \\
\frac{1}{4}\end{array}$ \\
\hline \multicolumn{5}{|c|}{ Formation enthalpy } \\
\hline$\Delta H_{f}(\mathrm{eV} /$ atom $)$ & $\begin{array}{c}\text { this work } \\
-0.49\end{array}$ & $\begin{array}{l}\text { ref. }{ }^{54} \\
-0.43\end{array}$ & & \\
\hline
\end{tabular}

Adsorption and co-adsorption energies On the clean surface, the most stable sites for the adsorption of $\mathrm{C}_{4} \mathrm{H}_{x}$ molecules $(x=6$ for butadiene and $x=8$ for butene) and hydrogen atoms were deduced from the calculation of adsorption energies $\left(E_{\text {ads }}^{X}\right.$, with $X=\mathrm{C}_{4} \mathrm{H}_{x}$ or $X=\mathrm{H}$ )

$$
\begin{gathered}
E_{a d s}^{\mathrm{C}_{4} \mathrm{H}_{x}}=E_{\text {tot }}-E_{\text {slab }}-E_{\mathrm{C}_{4} \mathrm{H}_{x}} \\
E_{a d s}^{n \mathrm{H}}=E_{\text {tot }}-E_{\text {slab }}-\frac{n}{2} E_{\mathrm{H}_{2}}
\end{gathered}
$$

where $E_{\text {slab }}, E_{X}$ and $E_{\text {tot }}$ are respectively the energies of the clean slab, the $X$ molecule in the gas phase, and the slab when $X$ is adsorbed. The interaction between the adsorbed molecule and the surface was analyzed in terms of the deformation energy $\operatorname{costs}\left(E_{d e f, m o l}^{\mathrm{C}_{4} \mathrm{H}_{x}}\right.$ and $E_{\text {def,surf }}^{\mathrm{C}_{4} \mathrm{H}_{x}}$ ) for relaxing the surface and the molecule upon forming the adsorbate complex from their respective isolated forms: $E_{a d s}^{\mathrm{C}_{4} \mathrm{H}_{x}}=E_{\text {def,mol }}^{\mathrm{C}_{4} \mathrm{H}_{x}}+E_{\text {def,surf }}^{\mathrm{C}_{4} \mathrm{H}_{x}}+$ $E_{\text {int }}^{\mathrm{C}_{4} \mathrm{H}_{x}}$, where $E_{\text {int }}^{\mathrm{C}_{4} \mathrm{H}_{x}}$ is the "true" interaction energy between the molecule and the surface.

Co-adsorption energies were also considered to feed the thermodynamic model described in the following. They are referred either to the clean surface (Eq. 4) or to the hydrogenated slab (Eq. 5), using:

$$
\begin{gathered}
E_{\text {clean-surf }}^{\mathrm{C}_{4} \mathrm{H}_{x}+n_{\mathrm{H}_{2} \mathrm{H}_{2}}}=E_{t o t}-E_{\text {slab }}-E_{\mathrm{C}_{4} \mathrm{H}_{x}}-\frac{n}{2} E_{\mathrm{H}_{2}} \\
E_{\mathrm{H}-\text { surf }}^{\mathrm{C}_{4} \mathrm{H}_{x}+n_{\mathrm{H}_{2} \mathrm{H}_{2}}}=E_{t o t}-E_{\text {slab }}^{n_{\mathrm{H}_{2} \mathrm{H}_{2}}}-E_{\mathrm{C}_{4} \mathrm{H}_{x}}
\end{gathered}
$$

In the previous equations, $E_{\text {slab }}^{n_{\mathrm{H}_{2} \mathrm{H}_{2}}}$ and $n=2 n_{\mathrm{H}_{2}}$ are the total energy of the hydrogenated slab and the number of hydrogen atoms adsorbed, respectively.

The thermodynamic feasibility of the hydrogenation was deduced from the comparison of the Gibbs free adsorption energy of butadiene and butene $\left(G_{a d s}^{\mathrm{C}_{4} \mathrm{H}_{x}}\right) .{ }^{57}$ 
These energies were computed as a function of the pressure $\left(p=p^{\mathrm{H}_{2}}+p^{\mathrm{C}_{4} \mathrm{H}_{\mathrm{x}}}\right)$ and the temperature $(T)$ :

$$
\begin{aligned}
G_{\text {ads }}^{\mathrm{C}_{4} \mathrm{H}_{x}}(T, p)= & E_{\text {clean-surf }}^{\mathrm{C}_{4} \mathrm{H}_{x}+n_{\mathrm{H}_{2}} \mathrm{H}_{2}} \\
& +k_{B} T \sum_{i \in \mathcal{X}} \ln \left(z_{\text {trans }}^{*, i} \cdot z_{\text {rot }}^{i}\right)^{n_{i}} \\
& -k_{B} T \sum_{i \in \mathcal{X}} n_{i} \ln \left(\frac{P^{i}}{k_{B} T}\right)
\end{aligned}
$$

with $\mathcal{X}=\left(n_{\mathrm{H}_{2}} \mathrm{H}_{2}, \mathrm{C}_{4} \mathrm{H}_{x}\right)$. The quantities $z_{\text {trans }}$ and $z_{\text {rot }}$ are the translational and rotational partition functions. They are calculated with $z_{\text {trans }}^{*, i}=\left(\frac{4 \pi m_{i} k_{B} T}{h^{2}}\right)^{\frac{3}{2}}$ and $z_{\text {rot }}^{i}=\frac{\pi^{1 / 2}}{\sigma_{r}}\left(\frac{8 \pi^{2} k_{B} T}{h^{2}}\right)^{\frac{3}{2}} I_{a} I_{b} I_{c}$ (details in S2). In this model, we considered an atmosphere made of $\mathrm{H}_{2}$ and $\mathrm{C}_{4} \mathrm{H}_{x}$ in the ratio $10: 1$.

\section{Surface models}

The $\mathrm{Al}_{5} \mathrm{Co}_{2}$ bulk structure belongs to the $\mathrm{P} 6_{3} / \mathrm{mmc}$ (hP28, 194) space group. ${ }^{53,58-60}$ The hexagonal cell contains 28 atoms (20 Al and $8 \mathrm{Co}$ ) and has the following lattice parameters: $a=b=7.6717 \AA$ and $c=7.6052$ A. A description based on a stacking of two types of

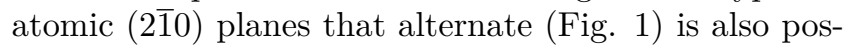
sible. More precisely, it involves a flat (F-type) and a puckered (P-type) plane containing 12 (4 Co and $8 \mathrm{Al}$ ) and 16 (4 Co and $12 \mathrm{Al}$ ) atoms in the surface unit cell, respectively.

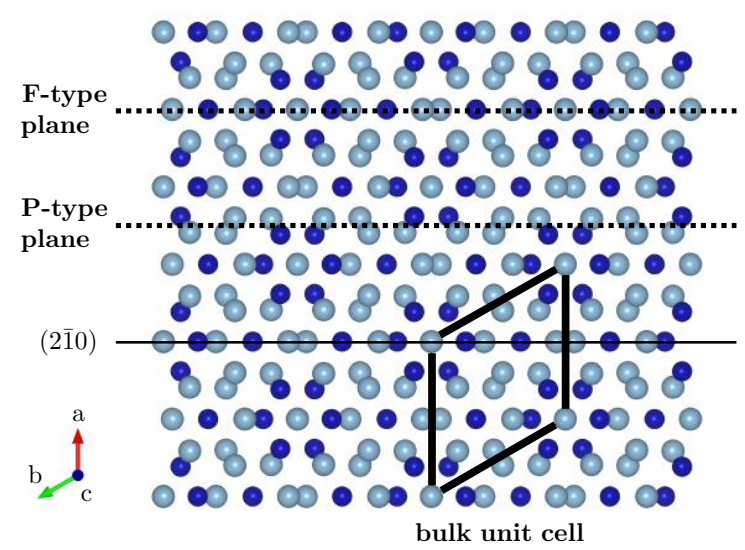

Figure 1: $\mathrm{Al}_{5} \mathrm{Co}_{2}$ bulk structure along the [100] direction

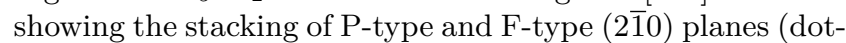
ted black lines). The conventional hexagonal cell is highlighted with thick dark lines. Al and Co atoms are drawn in light blue and dark blue, respectively.

According to our previous study, ${ }^{26}$ the $(2 \overline{1} 0)$ surface structure results from a bulk truncation and selection of the P-type (puckered) planes termination, with atomic rows missing, thus forming a $(2 \times 1)$ reconstruction. It means that the surface structure consists of nano-structured bands of $1.2 \mathrm{~nm}$ wide separated by 0.7 nm wide gaps. Several surface models were built, based on the knowledge gained by the experimental observations. Two of them fit equally well (for two different ranges of the allowed chemical potential) both STM and LEED measurements, and present low surface energies. However, the detailed surface composition, especially the presence/absence of these topmost surface Co atoms, could not be deduced from surface energy calculations, even combined with the comparison of simulated and experimental STM images.

Fig. 2 shows the four considered surface models, presenting different Co surface compositions. They include the $\mathrm{P}_{\mathrm{B}}$ and $\mathrm{P}_{\mathrm{B}-4 \mathrm{Co}}$ models investigated previously, with four and zero protruding Co atoms per surface cell, respectively, as well as two additional models: $\mathrm{P}_{\mathrm{B}-2 \mathrm{Co}, 1}$ and $\mathrm{P}_{\mathrm{B}-2 \mathrm{Co}, 2}$, both containing 2 protruding $\mathrm{Co}$ atoms per surface cell, and differing by the position of the surface Co vacancy.

\section{Results}

\section{Catalytic activity measurements}

The catalytic performances of $\mathrm{Al}_{5} \mathrm{Co}_{2}(2 \overline{1} 0)$ for butadiene hydrogenation were evaluated at $383 \mathrm{~K}$ in batch conditions, with initial hydrogen and butadiene partial pressures of 5 and 0.5 mbar, respectively. Fig. 3a displays three successive reaction runs. On the clean annealed surface (run 1), butadiene is fully converted after $30 \mathrm{~min}$, with $100 \%$ selectivity to butenes throughout the conversion. Butane is formed - at a slower rate - only after complete conversion of butadiene into butenes. The butadiene hydrogenation activity of $\mathrm{Al}_{5} \mathrm{Co}_{2}(2 \overline{1} 0)$ is similar to that of $\mathrm{Al}_{13} \mathrm{Co}_{4}(100) .{ }^{15}$

The model catalyst gradually deactivated from one run to the next. This is due to surface contamination with oxygen-containing impurities (mostly water) inherently present in gases, as previously shown by postreaction Auger electron spectroscopy for other transition metal aluminides. ${ }^{12,15}$

In Fig. 3b, the butenes distribution is shown in the case of the third reaction run. From $t=10 \mathrm{~min}$ to $t$ $=60 \mathrm{~min}$, it is about 65:24:11\% for 1-butene:trans-2butene:cis-2-butene, which is similar to the results for $\mathrm{Al}_{13} \mathrm{Co}_{4}$ surfaces. ${ }^{15}$ After complete conversion of butadiene, the butenes inter-convert through isomerization till thermodynamic equilibrium, with a final distribution of $9: 62: 29 \%$.

\section{Surface structure determination}

The surface energies of the four surface models described previously are shown in Fig. 4. The $\mathrm{P}_{\mathrm{B}}$ surface model is the most stable in the Co-rich limit $\left(\mu_{A l}-\mu_{A l}^{b u l k} \leq-0.5 \mathrm{eV} / \mathrm{at}\right)$, while it is the $\mathrm{P}_{\mathrm{B}-4 \mathrm{Co}}$ one in the Al-rich limit $\left(-0.36 \mathrm{eV} /\right.$ at $\left.\leq \mu_{A l}-\mu_{A l}^{b u l k}\right)$. The two additional models $\left(\mathrm{P}_{\mathrm{B}-2 \mathrm{Co}, 1}\right.$ and $\left.\mathrm{P}_{\mathrm{B}-2 \mathrm{Co}, 2}\right)$ present similar surface energies. They are the most stable ones for intermediate values of the chemical potentials, no significant energy difference being calculated between these 

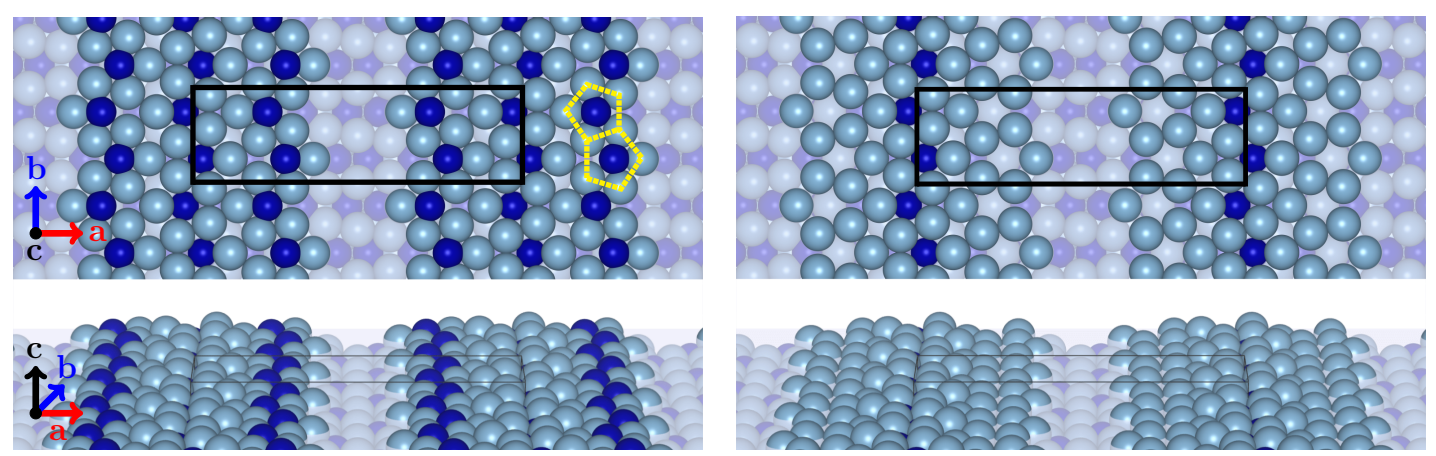

(a) $\mathrm{P}_{\mathrm{B}}$

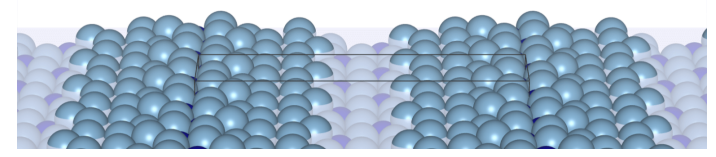

(b) $\mathrm{P}_{\mathrm{B}-4 \mathrm{Co}}$
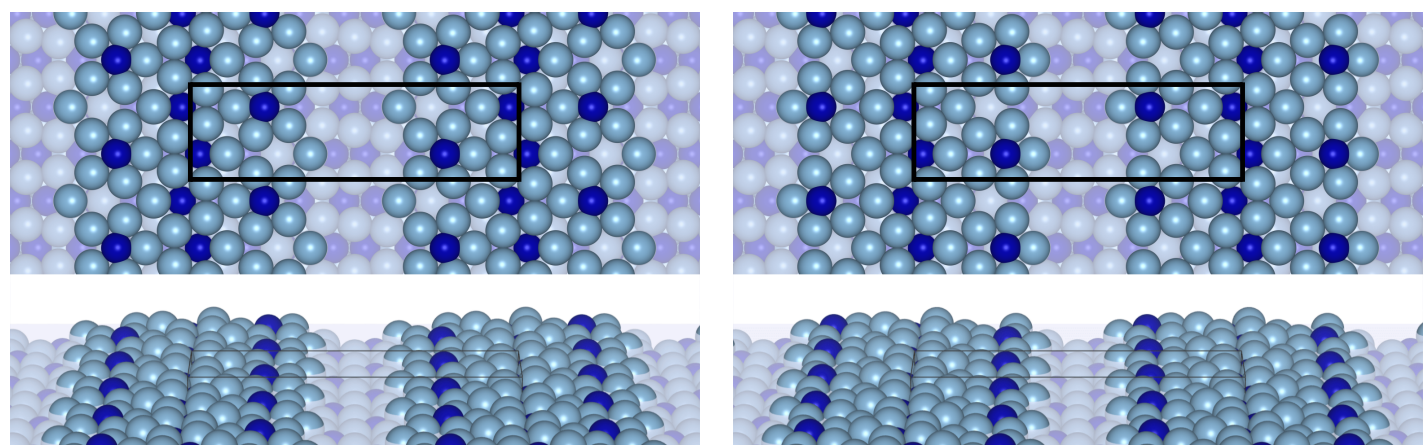

(c) $\mathrm{P}_{\mathrm{B}-2 \mathrm{Co}, 2}$

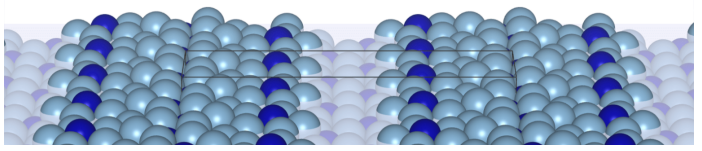

(d) $\mathrm{P}_{\mathrm{B}-2 \mathrm{Co}, 1}$

Figure 2: Top and perspective views of the surface models considered in this study. Al atoms and Co atoms are respectively drawn in light blue and dark blue. The surface cells are highlighted with black lines (top views). The yellow pentagons highlight the atomic Al pentagonal arrangements surrounding surface Co atoms.
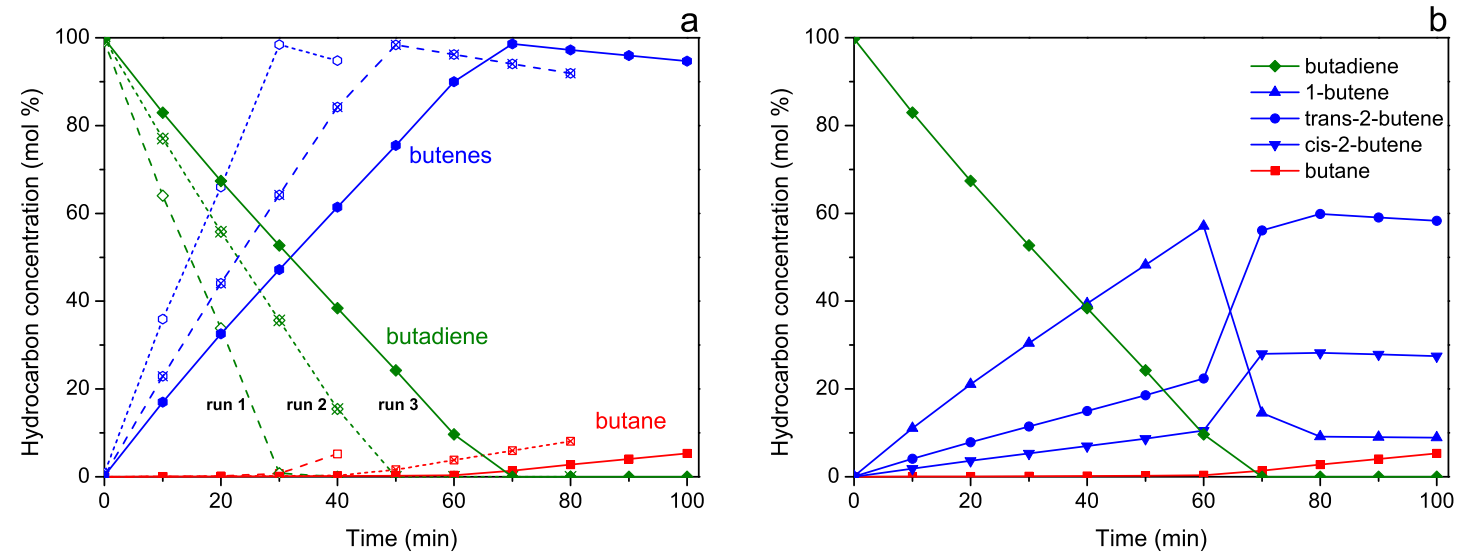

Figure 3: (a) Catalytic performances of $\mathrm{Al}_{5} \mathrm{Co}_{2}(2 \overline{1} 0)$ at $\mathrm{T}=383 \mathrm{~K}$, with initial pressures $\mathrm{p}_{\mathrm{H}_{2}}=5$ mbar and $\mathrm{p}_{\mathrm{C}_{4} \mathrm{H}_{6}}=0.5 \mathrm{mbar}$ (first, second and third runs are respectively drawn in dashed, dotted and full lines). (b) Detailed catalytic performances of $\mathrm{Al}_{5} \mathrm{Co}_{2}(2 \overline{1} 0)$ for the third run showing the concentrations of the different butene isomers.

two models. Although these results assess the stability of the considered surface models, they do not provide any accurate information about the surface composition of the sample used for the catalytic measurements, since the chemical potentials depend on the exact composition of the single crystalline ingot used for the experiments (amount of vacancies, anti-sites, etc). ${ }^{61,62}$

The comparison of the experimental and STM images simulated using the four considered models is shown in Fig. 5. The position of Co atoms located slightly below the neighboring pentagonal atomic arrangements present in all models results in very similar simulated images. While in agreement with the experimental STM images, it is then not possible to discriminate among the different models simply based on STM images.

The surface structure was further investigated using SXRD. Fig. 6 shows the in-plane measurement of the reciprocal space highlighting (circled in blue) a 


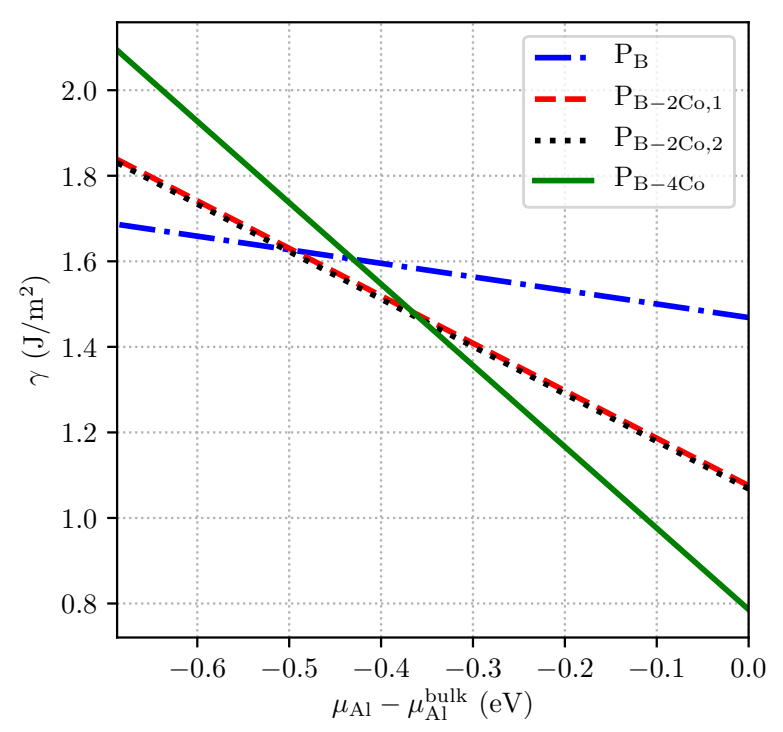

Figure 4: Calculated surface energies as a function of the $\mathrm{Al}$ chemical potential.

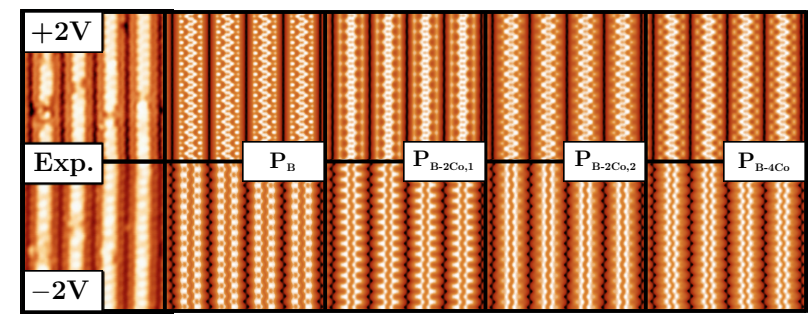

Figure 5: Experimental STM images (adapted from Ref. ${ }^{26}$ ), $\mathrm{P}_{\mathrm{B}}, \mathrm{P}_{\mathrm{B}-2 \mathrm{Co}, 1}, \mathrm{P}_{\mathrm{B}-2 \mathrm{Co}, 2}$ and $\mathrm{P}_{\mathrm{B}-4 \text { Co }}$ simulated $\mathrm{STM}$ images $\left(V_{b}= \pm 2 \mathrm{~V}\right)$.

pseudo 10-fold symmetry, i.e. nonequivalent in-plane reflections forming an irregular decagon. This is in agreement with the surface pentagonal atomic arrangements (Fig. 2a) which induce a modulation of the inplane structure factors, thus allowing this particular symmetry to emerge on a rectangular lattice. The inplane reciprocal space measurements also confirm the $(2 \times 1)$ surface reconstruction. Measured lattice parameters $\left(a_{\text {exp }}=26.7(8) \AA\right.$ and $\left.b_{\exp }=7.6(3) \AA\right)$ are in good agreement with the literature ${ }^{53}\left(a_{\text {lit }}=26.58 \AA\right.$ and $\left.b_{l i t}=7.61 \AA\right)$. Out-of-plane measurements were also done and 49 diffraction rods were collected. The complete dataset consists of 12 non-equivalent Crystal Truncation Rods (CTRs) and 10 non-equivalent Super Structure Rods (SSRs). Each rod was measured for $0 \leq L \leq 5$. Another set of diffraction spots is also observed (highlighted in green in Fig. 6). The lattice parameters $\left(b_{\text {exp }}=2.87(1) \AA\right.$ and $\left.a_{\text {exp }}=c_{\text {exp }}=4.06 \AA\right)$ are consistent with those of the B2-AlCo (110) surface $\left(a_{l i t}=2.862 \AA, a_{l i t} \sqrt{2}=4.047 \AA{ }^{63}\right)$. This might be due to the presence of $\mathrm{B} 2-\mathrm{AlCo}$ - either in the bulk material and/or at the surface.

The simulations of the CTRs and SSRs were performed based on the four considered surface models, whose structures were relaxed using DFT calculations (Fig. 7). The only needed free parameter for the simulations was the scaling factor (ca. 0.040 and ca. 0.037 for the CTR and SSR calculations, respectively). All simulations reproduce quite well several CTRs and SSRs features such as surface-related anti Bragg positions (e.g. CTRs $(0,2)$ or $(8,1))$. CTR $\chi^{2}$ calculations show that models which present protruding Co atoms are more suitable. However, SSR $\chi^{2}$ calculations are required to discriminate between the four models (SSRs are more sensitive to the surface structure). The $\mathrm{P}_{\mathrm{B}-2 \mathrm{Co}, 1} \chi^{2}$ is indeed lower than the others $\left(\chi_{\mathrm{SSR}}^{2}=3.33\right.$ and $\chi_{\mathrm{CTR}}^{2}=5.13$, see Tab. 2). The improvement of $\chi^{2}$ is of almost $10 \%$ from the $\mathrm{P}_{\mathrm{B}}$ model to the new model proposed for this surface $\left(\mathrm{P}_{\mathrm{B}-2 \mathrm{Co}, 1}\right)$. It reaches $25 \%$ when considering only the SSRs. One cannot however exclude a combination of several models.

The combination of surface energy calculations and experimental approaches allows the identification of the $\mathrm{P}_{\mathrm{B}-2 \mathrm{Co}, 1}$ model to describe the surface structure. In the following, we used this model to perform the investigation of the surface adsorption properties.

Table 2: Comparison between the four DFT-based surface structures and SXRD measurements : $\chi^{2}$ calculations

\begin{tabular}{c|cc|c}
\hline Model & SSRs $\chi^{2}$ & CTRs $\chi^{2}$ & Global $\chi^{2}$ \\
\hline $\mathrm{P}_{\mathrm{B}}$ & 4.19 & 5.19 & 4.74 \\
$\mathbf{P}_{\mathrm{B}-\mathbf{2 C o}, \mathbf{1}}$ & $\mathbf{3 . 3 3}$ & $\mathbf{5 . 1 3}$ & $\mathbf{4 . 3 2}$ \\
$\mathrm{P}_{\mathrm{B}-2 \mathrm{Co}, 2}$ & 4.54 & 5.18 & 4.89 \\
$\mathrm{P}_{\mathrm{B}-4 \mathrm{Co}}$ & 4.44 & 5.32 & 4.93 \\
\hline
\end{tabular}

\section{Adsorption and Co-adsorption properties of the $\mathrm{P}_{\mathrm{B-2Co,1}}$ surface model}

The determination of adsorption properties for butadiene and butene molecules on $\mathrm{Al}_{5} \mathrm{Co}_{2}(2 \overline{1} 0)$ is a prerequisite to feed the thermodynamic model used in the following to analyze the catalytic properties of $\mathrm{Al}_{5} \mathrm{Co}_{2}(2 \overline{1} 0)$. The complex energy landscape of this surface may however lead to a huge number of adsorption sites, including several molecular configurations for the adsorbates. Rather than performing a systematic, blindfolded and computationally expensive search, we preferred to rely on the knowledge gained from our previous study, which identified favorable adsorption sites for atomic hydrogen, acetylene and ethylene, using the $\mathrm{P}_{\mathrm{B}}$ and $\mathrm{P}_{\mathrm{B}-4 \mathrm{Co}}$ models. ${ }^{27}$

Atomic hydrogen adsorption According to ref., ${ }^{27}$ the Co-rich surface model $\left(\mathrm{P}_{\mathrm{B}}\right)$ presents a large number of exothermic adsorption sites for atomic hydrogen. Most atomic hydrogen adsorption sites are found close to a protruding surface Co atom (\#i, $i \in$ $\{1,2,4,5,7,8,10,11\}$, Fig. 8, labels from ref. ${ }^{27}$ ) with adsorption energies in the range $[-0.39 \mathrm{eV},-0.14 \mathrm{eV}]$, or on top of the Co atoms belonging to the subsurface 


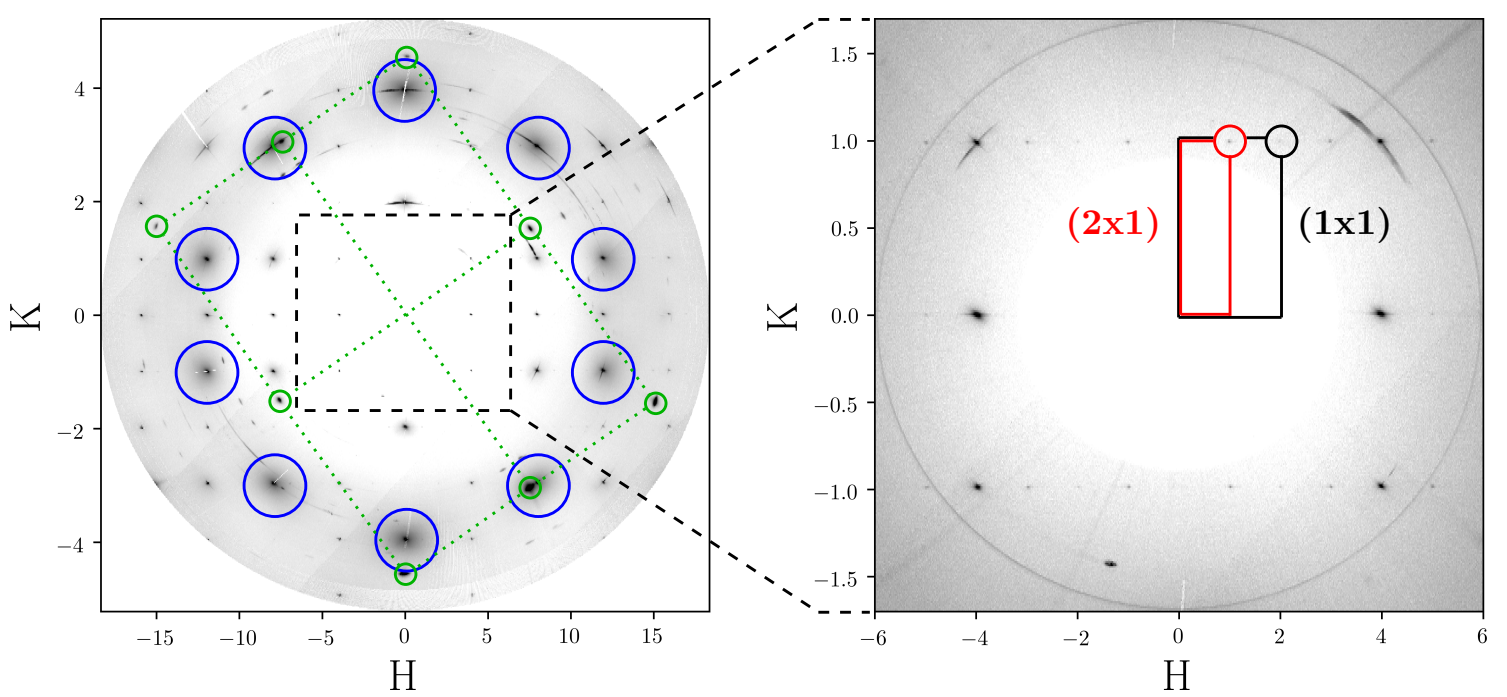

Figure 6: In-plane reciprocal space map of $\mathrm{Al}_{5} \mathrm{Co}_{2}(2 \overline{1} 0)$ : (left) full map highlighting the pseudo 10-fold symmetry in blue circles and the B2-AlCo (110) diffraction spots in green circles, (right) inner map showing the $(2 \times 1)$ surface reconstruction cell.

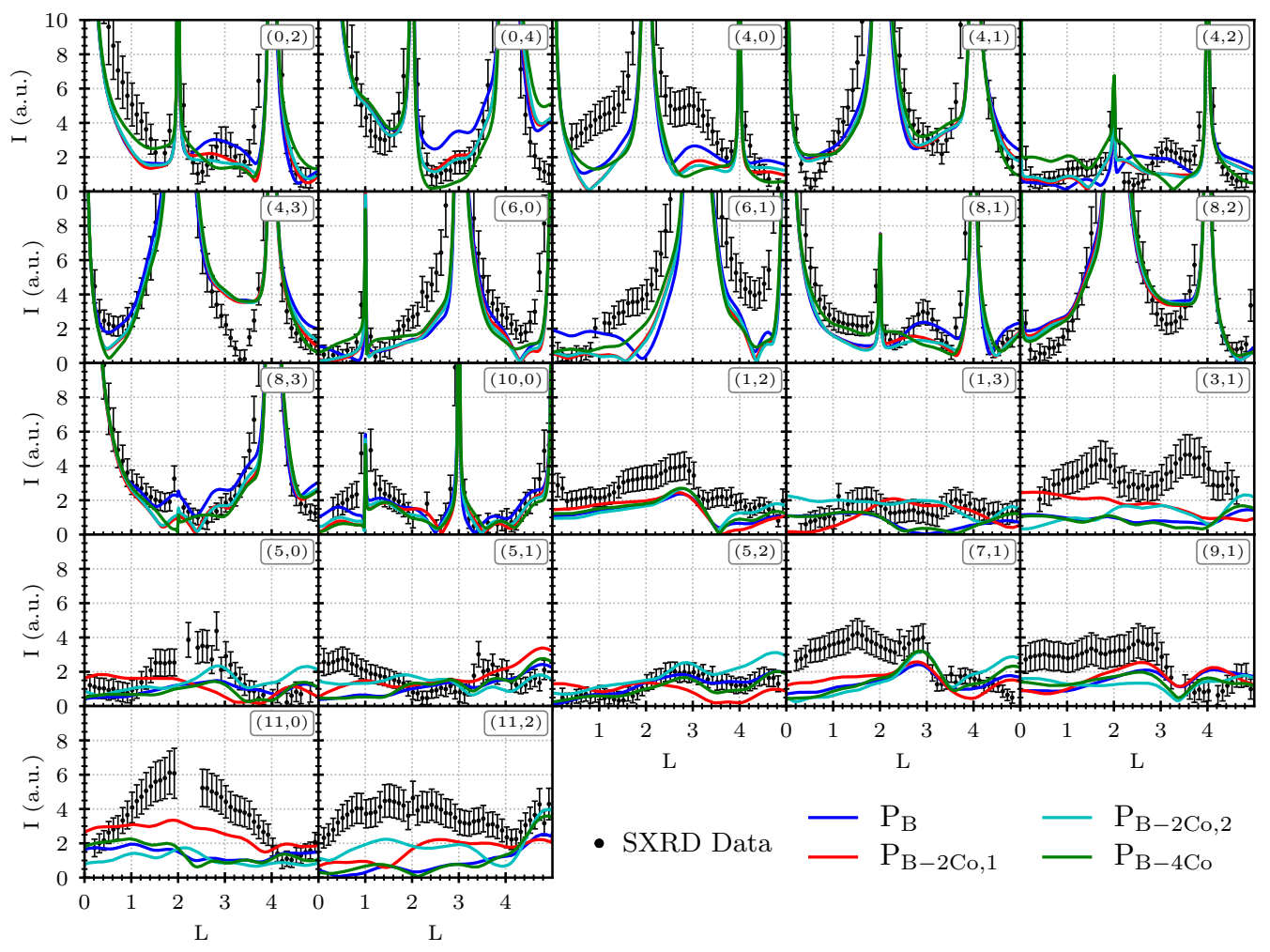

Figure 7: Measured crystal truncation rods (CTRs, even values of $\mathrm{H}$ ) and super structure rods (SSRs, odd values of $\mathrm{H}$ ) of $\mathrm{Al}_{5} \mathrm{Co}_{2}(2 \overline{1} 0)$ and the related DFT-based simulations of the four surface models.

atomic plane (\#6, $\left.E_{a d s}=-0.31 \mathrm{eV}\right)$, as well as on top of a specific $\mathrm{Al}$ surface atom $\left(\# 3, E_{a d s}=-0.36 \mathrm{eV}\right)$. The number of favorable adsorption sites is reduced when protruding atoms are missing at the surface (Al-rich $\mathrm{P}_{\mathrm{B}-4 \mathrm{Co}}$ surface model). Only a few sites are favorable: $\# i$ ' with $i^{\prime} \in\{3,4,6,7,10,11\}$ with adsorption energies in the range $[-0.37 \mathrm{eV},-0.09 \mathrm{eV}]$.
Butadiene adsorption According to previous studies ${ }^{15,64-66}$ stable sites for the adsorption of unsaturated molecules with carbon-carbon double bonds, like ethylene and butadiene, on complex polar intermetallic surfaces, generally occur through a $\pi$-bonding to a surface protruding transition metal atom. On $\mathrm{Al}_{5} \mathrm{Co}_{2}(2 \overline{1} 0)$, the di- $\sigma$ configuration $\left(\sigma_{\mathrm{Al}} \sigma_{\mathrm{Al}}\right)$, was identified as a stable site as well. ${ }^{27}$ In the following, we then consider only four configurations for butadiene and butene on 


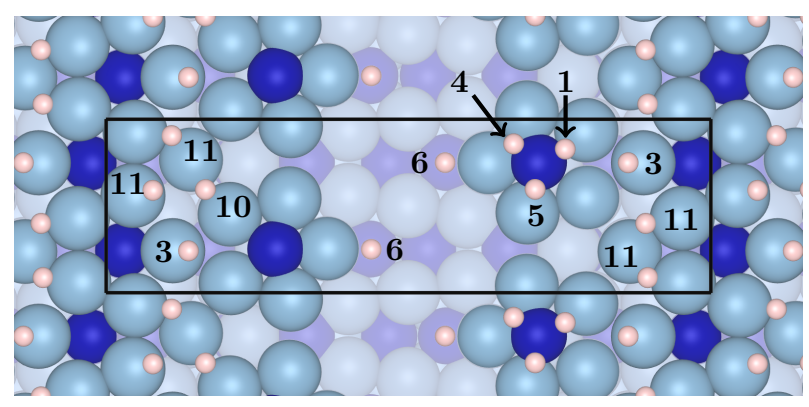

Figure 8: Co-adsorption of 12 hydrogen atoms (labelled $i$, $i \in\{1,3,4,5,6,10,11\})$ on $\mathrm{P}_{\mathrm{B}-2 \mathrm{Co}, 1}$. The surface unit cell is drawn in black. The color code is the same as Fig. 2.

$\mathrm{Al}_{5} \mathrm{Co}_{2}(2 \overline{1} 0)$ : three starting configurations $(\mathrm{A}, \mathrm{B}$ and $\mathrm{C})$ involve a $\mathrm{C}=\mathrm{C}$ bond on top of a surface protruding/vacancy Co atom and one configuration (D) involves the $\sigma_{\mathrm{Al}} \sigma_{\mathrm{Al}}$ configuration (Fig. S3, Tab. S1 and Tab. S2).

The most stable site (Fig. 9a, labelled A in Fig. S3) is a $\pi_{\mathrm{Co}}($ allyl $) \sigma_{\mathrm{Al}}(\mathrm{C})$ site $\left(E_{\text {ads }}^{\mathrm{C}_{4} \mathrm{H}_{6}}=-1.92 \mathrm{eV}\right)$. The molecule is slightly deformed $\left(E_{\text {def,mol }}^{\mathrm{C}_{4} \mathrm{H}_{6}}=1.10\right.$ $\mathrm{eV}$ ), with a $\mathrm{C}-\mathrm{C}$ bond length of the allyl radical similar to the one of the free radical $\left(1.43 \AA^{67}\right)$. Other favorable adsorption configurations include di- $\pi$ bonds $\left(\pi_{\mathrm{Al}}(\mathrm{CC}) \pi_{\mathrm{Co}}(\mathrm{CC}), E_{\text {ads }}^{\mathrm{C}_{4} \mathrm{H}_{6}}=-1.74 \mathrm{eV}\right)$ or tri- $\sigma$ bonds $\left(\operatorname{tri} \sigma_{\mathrm{Al}}(\mathrm{C}), E_{a d s}^{\mathrm{C}_{4} \mathrm{H}_{6}}=-1.72 \mathrm{eV}\right)$. Physisorbed butadiene is less bounded on the surface $\left(E_{a d s}^{\mathrm{C}_{4} \mathrm{H}_{6}}=-0.53 \mathrm{eV}\right)$.

As expected, a stronger butadiene $/ \mathrm{Al}_{5} \mathrm{Co}_{2}(2 \overline{1} 0)$ interaction was identified on the Co-rich surface model $\left(\mathrm{P}_{\mathrm{B}}\right.$ model $)$, with butadiene adsorbed in between the two closest protruding Co atoms $\left(\pi_{\mathrm{Co}}(\right.$ allyl $) \sigma_{\mathrm{Al}}(\mathrm{C})$, $\left.E_{\text {ads }}^{\mathrm{C}_{4} \mathrm{H}_{6}}=-2.26 \mathrm{eV}\right)$. More interesting, such a strong adsorption energy is calculated on the Al-rich surface model as well $\left(\mathrm{P}_{\mathrm{B}-4 \mathrm{Co}}\right.$ model, $\left.E_{\text {ads }}^{\mathrm{C}_{4} \mathrm{H}_{6}}=-2.27 \mathrm{eV}\right)$. Butadiene is adsorbed with a $1,4-\mathrm{di} \sigma-2,3 \pi$ configuration, in a site involving $\mathrm{Al}$ atoms, neighboring of the surface Co vacancies. The molecule is strongly distorted $\left(E_{\text {def,mol }}^{\mathrm{C}_{4} \mathrm{H}_{6}}=1.90 \mathrm{eV}\right)$, but the 'true' interaction energy is large $\left(E_{\text {int }}^{\mathrm{C}_{4} \mathrm{H}_{6}}=-4.35 \mathrm{eV}\right)$. This shows that the presence of a protruding Co-site at the surface is not required to strongly adsorb the butadiene molecule.

Butene adsorption The most favorable adsorption site for butene on $\mathrm{Al}_{5} \mathrm{Co}_{2}(2 \overline{1} 0)\left(\mathrm{P}_{\mathrm{B}-2 \mathrm{Co}, 1}\right.$ model $)$ is a $\pi_{\mathrm{Co}}$ configuration, with an adsorption energy equal to -1.52 eV (Tab. 3, Fig. 9b and Tab. S3). A di- $\sigma$ configuration involving one $\mathrm{Al}-\mathrm{Al}$ pair, is also identified, with a lower adsorption energy $\left(E_{a d s}^{\mathrm{C}_{4} \mathrm{H}_{8}}=-1.25 \mathrm{eV}\right)$. Physisorption leads to smaller adsorption energies $\left(E_{a d s}^{\mathrm{C}_{4} \mathrm{H}_{8}}=-0.51\right.$ $\mathrm{eV})$.

Here, since the strongest butene adsorption occurs through a $\pi$ bonding involving only one surface protruding Co atom, it is not surprising to obtain similar strongest adsorption energies on the $\mathrm{P}_{\mathrm{B}-2 \mathrm{Co}, 2}$ and $\mathrm{P}_{\mathrm{B}}$ models $\left(E_{a d s}^{\mathrm{C}_{4} \mathrm{H}_{8}} \in[-1.48 ;-1.54] \mathrm{eV}\right)$. Again, the presence of a protruding surface Co atom is not mandatory for the adsorption properties, since di- $\sigma_{\mathrm{Al}}$ and $\sigma_{\mathrm{Al}} \sigma_{C o}$ also lead to large adsorption energies $\left(E_{\text {ads }}^{\mathrm{C}_{4} \mathrm{H}_{8}}=-1.37\right.$ $\mathrm{eV}$ on the $\mathrm{P}_{\mathrm{B}-4 \mathrm{Co}}$ model, for example).

Table 3: Trans-1,3-butadiene $\left(\mathrm{C}_{4} \mathrm{H}_{6}\right)$ and 1-butene $\left(\mathrm{C}_{4} \mathrm{H}_{8}\right)$ adsorption energies on $\mathrm{P}_{\mathrm{B}-2 \mathrm{Co}, 1}$

\begin{tabular}{c|cccc}
\hline \multirow{2}{*}{$\mathrm{P}_{\mathrm{B}-2 \mathrm{Co}, 1}$} & \multicolumn{5}{|c}{$\mathrm{E}_{\text {ads }}(\mathrm{eV})$ for different sites } \\
& $\mathrm{A}$ & $\mathrm{B}$ & $\mathrm{C}$ & $\mathrm{D}$ \\
\hline $\mathrm{C}_{4} \mathrm{H}_{6}$ & -1.92 & -1.74 & $-0.53^{\varphi}$ & -1.72 \\
\hline$\chi-\mathrm{C}_{4} \mathrm{H}_{8}$ & -1.52 & -1.54 & $-0.51^{\varphi}$ & -1.25 \\
\hline$\varphi-\mathrm{C}_{4} \mathrm{H}_{8}$ & -0.61 & -0.63 & $-0.36^{\varphi}$ & -0.82 \\
\hline \multicolumn{4}{c}{$\chi$ : chemisorbed, $\varphi$ : physisorbed }
\end{tabular}

Co-adsorption of alkene and hydrogen Atomic hydrogen and $\mathrm{C}_{4} \mathrm{H}_{6}$ need to be simultaneously adsorbed on the surface for the hydrogenation reaction to occur according to the Langmuir-Hinshelwood mechanism. Here, we determine how the previous adsorption energies are impacted by co-adsorption with hydrogen under realistic conditions (pressure, temperature). Seven considered coverages $\left(\theta_{H}=0,2,4,6,8,10\right.$ or 12 atomic hydrogen per surface cell) are considered for co-adsorption. The hydrogen adsorption sites are selected amongst the one presented in Fig. 8 following their relative adsorption energies (details in S2, Tab. S4 and Tab. S5).

Using the $\mathrm{P}_{\mathrm{B}-2 \mathrm{Co}, 1}$ model, the thermodynamic diagrams related to the co-adsorption of hydrogen and butadiene/butene (chemi- and physisorbed), as well as the corresponding hydrogen coverages $\left(\theta_{H}\right)$, are plotted as a function of the temperature and the total pressure, in Figs. 10(a-f). Butadiene is shown to be adsorbed with a coadsorption enthalpy of $-1.84 \mathrm{eV}$ under experimental hydrogenation conditions, the optimum hydrogen coverage being $\theta_{H}=6$. Additional hydrogen atoms are present at the surface for the $\mathrm{C}_{4} \mathrm{H}_{8}$ co-adsorption $\left(\theta_{H}=8\right.$, coadsorption enthalpy of $-1.49 \mathrm{eV}$ and -0.49 $\mathrm{eV}$ for the chemi- and physi-sorbed modes, respectively).

\section{Discussion}

\section{Competition between chemisorbed and physisorbed butene}

There are two possible ways to obtain 1-butene from adsorbed butadiene (site A) : through the hydrogenation of the $\mathrm{C}=\mathrm{C}$ fragment bounded either to one surface $\mathrm{Co}$ or to one $\mathrm{Al}$ surface atom. In the latter scenario 1-butene is chemisorbed while in the first case it is physisorbed. Both products - chemisorbed or physisorbed butene - appear to be adsorbed at $\mathrm{p}=5.5 \mathrm{mbar}$ and $\mathrm{T}$ $=383 \mathrm{~K}$ (experimental conditions).

Chemisorbed butene on $\mathrm{P}_{\mathrm{B}-2 \mathrm{Co}, 1}$ leads to a $\pi_{\mathrm{Co}}$ configuration with an adsorption energy equal to $-1.52 \mathrm{eV}$ (Tab. 3, Fig. 9b and Tab. S3). This rather large adsorption energy results from the strong molecule surface 


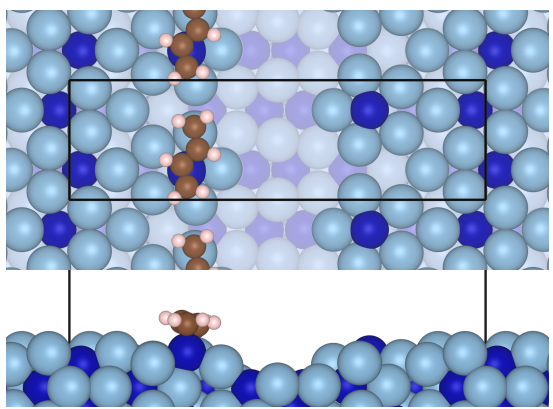

(a) $\mathrm{C}_{4} \mathrm{H}_{6}$

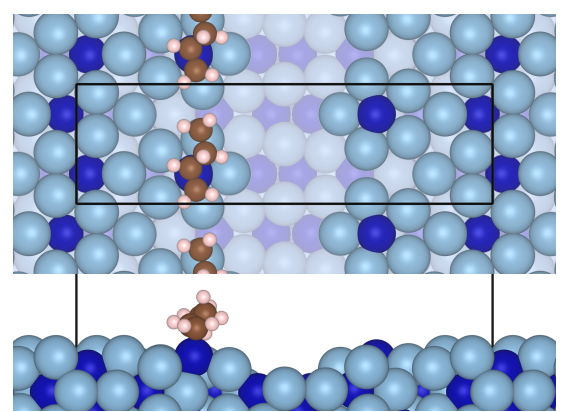

(b) $\chi-\mathrm{C}_{4} \mathrm{H}_{8}$ (chemisorbed)

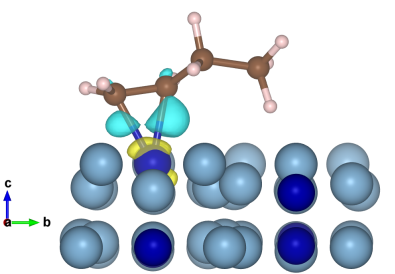

(e) $\chi-\mathrm{C}_{4} \mathrm{H}_{8}$ (chemisorbed)

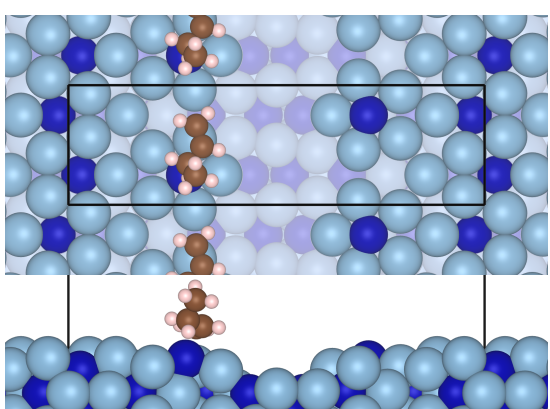

(c) $\varphi-\mathrm{C}_{4} \mathrm{H}_{8}$ (physisorbed)

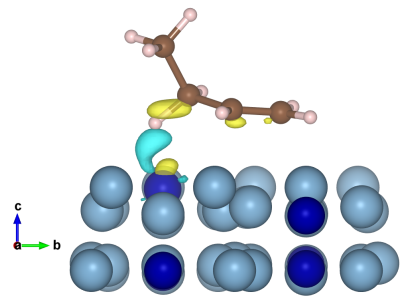

(f) $\varphi-\mathrm{C}_{4} \mathrm{H}_{8}$ (physisorbed)

Figure 9: Adsorption configurations on $\mathrm{P}_{\mathrm{B}-2 \mathrm{Co}, 1}$ (site A) for (a) $\mathrm{C}_{4} \mathrm{H}_{6}$, (b) $\chi-\mathrm{C}_{4} \mathrm{H}_{8}$ (chemisorbed through a double $\mathrm{C}=\mathrm{C}$ bond on a protruding Co atom) and (c) $\varphi-\mathrm{C}_{4} \mathrm{H}_{8}$ (physisorbed through a $\mathrm{H}$ atom on a Co atom). Isosurface of charge density differences for $(\mathrm{d}) \mathrm{C}_{4} \mathrm{H}_{6}\left(0.01 \mathrm{e}^{-} / \AA^{3}\right)$, (e) $\chi-\mathrm{C}_{4} \mathrm{H}_{8}\left(0.01 \mathrm{e}^{-} / \AA^{3}\right)$ and $(\mathrm{f}) \varphi-\mathrm{C}_{4} \mathrm{H}_{8}\left(0.006 \mathrm{e}^{-} / \AA^{3}\right)$. Negative (resp. positive) isosurfaces are plotted in light blue (resp. yellow).

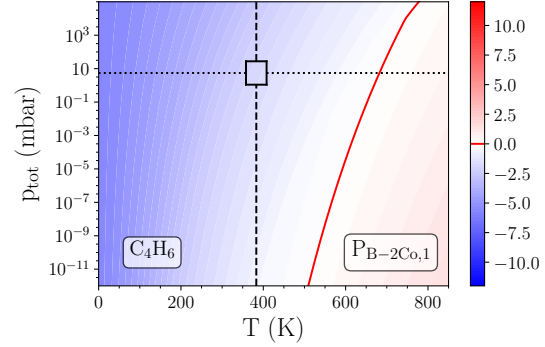

(a)

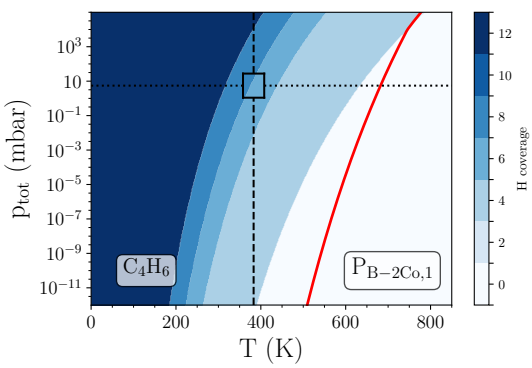

(d) $\theta_{H}+\mathrm{C}_{4} \mathrm{H}_{6}$

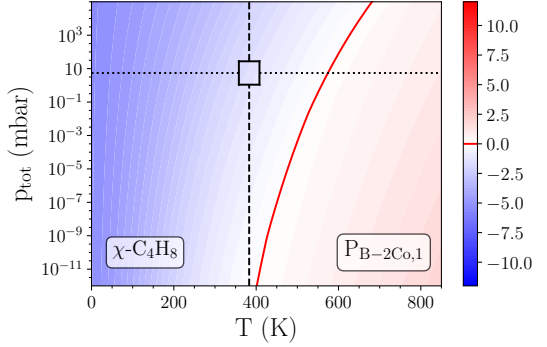

(b)

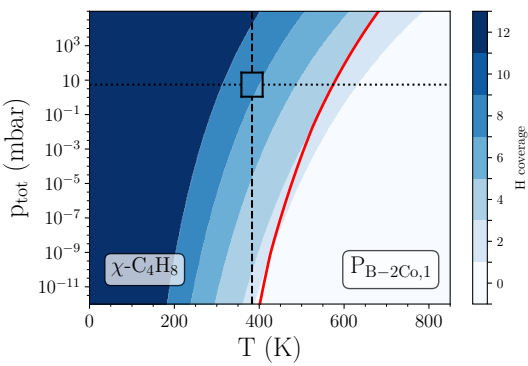

(e) $\theta_{H}+\chi-\mathrm{C}_{4} \mathrm{H}_{8}$

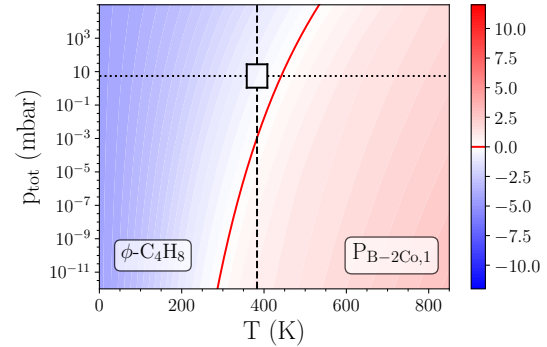

(c)

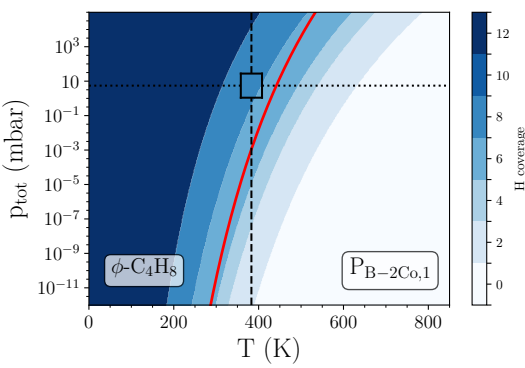

(f) $\theta_{H}+\varphi-\mathrm{C}_{4} \mathrm{H}_{8}$

Figure 10: Co-adsorption enthalpy in $\mathrm{eV}$ (color scale) of (a) hydrogen atoms and $\mathrm{C}_{4} \mathrm{H}_{6}$, (b) hydrogen atoms and $\varphi-\mathrm{C}_{4} \mathrm{H}_{8}$ and (c) hydrogen atoms and $\chi-\mathrm{C}_{4} \mathrm{H}_{8}$, as a function of $\mathrm{p}$ and $\mathrm{T}$ for $\mathrm{P}_{\mathrm{B}-2 \mathrm{Co}, 1}$. Corresponding hydrogen coverage as a function of $\mathrm{p}$ and $\mathrm{T}$ plotted for $(\mathrm{d})$ hydrogen atoms and $\mathrm{C}_{4} \mathrm{H}_{6},(\mathrm{e})$ hydrogen atoms and $\chi-\mathrm{C}_{4} \mathrm{H}_{8}$ and (f) hydrogen atoms and $\varphi-\mathrm{C}_{4} \mathrm{H}_{8}$ for $\mathrm{P}_{\mathrm{B}-2 \mathrm{Co}, 1}$ model. $\chi$ - and $\varphi$ - respectively describe chemisorbed and physisorbed $\mathrm{C}_{4} \mathrm{H}_{8}$. The red line represents $\mathrm{G}_{\mathrm{ads}}=0$. The dotted and dashed lines respectively represent $\mathrm{p}=5.5 \mathrm{mbar}, \mathrm{T}=383 \mathrm{~K}$ i.e. the experimental conditions.

bonding, involving charge transfer (3 lobes of charge accumulation between the molecule and the surface, Fig. 9e). An iono-covalent character is expected for the bonding, the covalent character of the $\mathrm{C}-\mathrm{Al}$ bond being corroborated by the calculation of the electron localization function.

Physisorbed butene leads to a smaller adsorption energy $\left(E_{a d s}^{\mathrm{C}_{4} \mathrm{H}_{8}}=-0.51 \mathrm{eV}\right)$. Charge deformation (Fig. 9f) 
highlights a bonding through one hydrogen atom.

According to the experimental results obtained at $(\mathrm{p}, \mathrm{T})=(5$ mbar, $393 \mathrm{~K})$, butene has to be desorbed once produced since a 100\% selectivity towards semihydrogenation as well as full conversion are observed. Our thermodynamic study predicts a desorption temperature of $440 \mathrm{~K}$ for $\varphi-\mathrm{C}_{4} \mathrm{H}_{8}$, which is only $57 \mathrm{~K}$ higher than the experimental temperature. Conversely, it is calculated that $\chi-\mathrm{C}_{4} \mathrm{H}_{8}$ would desorb at $\mathrm{T}=572 \mathrm{~K}$ (189 $\mathrm{K}$ higher than $\mathrm{T}_{\exp }$, Fig. $\mathrm{S} 4$ ). Uncertainties are still present on the experimental temperature measurements and on the desorption temperature calculations. Nevertheless, the combination of experimental and theoretical results may indicate that the $\pi_{\mathrm{Co}}$ (allyl) bond is hydrogenated first. Such a conclusion should however be strengthened by the evaluation of a possible reaction path on the surface, which is out of the scope of this paper.

\section{Influence of surface Co atoms}

Adsorption properties are found to be strongly influenced by the density of surface protruding Co atoms (Fig. S5). When comparing the $\mathrm{P}_{\mathrm{B}}$ and $\mathrm{P}_{\mathrm{B}-2 \mathrm{Co}, 1}$ models, one observes that molecules are more strongly adsorbed at the Co-rich surface model, as already noticed in our preliminary calculations without atmosphere.

The previous observations have a consequence on the catalytic properties. Using the $\mathrm{P}_{\mathrm{B}}$ model, with 4 protruding cobalt atoms, the most stable site involves 2 protruding surface Co atoms $\left(E_{a d s}=-2.26 \mathrm{eV}\right.$, Tab. $\mathrm{S} 1$ ), leading to a rather high adsorption energy. Whatever the double bond that is hydrogenated first, the hydrogenated molecule (1-butene) is strongly adsorbed as well, through one Co atom, which may prevent a good selectivity.

A strong molecule surface interaction was already calculated for acetylene on the $\mathrm{P}_{\mathrm{B}}$ model. This was shown to alter the activity of the catalyst: in ref., ${ }^{27}$ the considered reaction path did not consider the most stable site, because in this case the adsorption energies of the reactants are more stable than the products.

Using the $\mathrm{P}_{\mathrm{B}-2 \mathrm{Co}, 1}$ model, only one protruding $\mathrm{Co}$ atom is involved in the bonding between the surface and butadiene. Protruding surface Co atoms are isolated, which may favor the selectivity. When the $\pi_{\mathrm{Co}-\text { allyl }}$ bonding is hydrogenated first, this scenario is shown to lead to theoretical results in agreement with the catalytic observations.

\section{Adsorption and catalytic properties}

Several surfaces of Al-based approximants to decagonal quasicrystals have been identified as possible catalysts for butadiene hydrogenation. It is the case for $\mathrm{Al}_{13} \mathrm{Co}_{4}(100), \mathrm{Al}_{13} \mathrm{Co}_{4}(010), \mathrm{Al}_{13} \mathrm{Ru}_{4}(010)$, $\mathrm{Al}_{13} \mathrm{Fe}_{4}(010)$ and $\mathrm{Al}_{5} \mathrm{Co}_{2}(2 \overline{1} 0) \cdot{ }^{10,12,15}$ While these surfaces (apart from $\mathrm{Al}_{13} \mathrm{Co}_{4}(010)$ ) present structural similarities - pentagonal arrangement of $\mathrm{Al}$ atoms embed- ding a transition metal atom - their adsorption properties and catalytic performances are quite different. The adsorption energies of butadiene and butene increase when considering successively the $\mathrm{Al}_{13} \mathrm{Co}_{4}(100)$, $\mathrm{Al}_{13} \mathrm{Fe}_{4}(010)$ and $\mathrm{Al}_{5} \mathrm{Co}_{2}(2 \overline{1} 0)$ surfaces, with values ranging from $-1.59 \mathrm{eV},-1.80 \mathrm{eV}$ to $-1.92 \mathrm{eV}$ for butadiene and from $-1.13 \mathrm{eV},-1.38 \mathrm{eV}$ to $-1.52 \mathrm{eV}$ for butene. Hydrogen adsorption energies are similar on $\mathrm{Al}_{13} \mathrm{Fe}_{4}(010)$ and $\mathrm{Al}_{5} \mathrm{Co}_{2}(2 \overline{1} 0)$ - they are $-0.41 \mathrm{eV}$ and $-0.39 \mathrm{eV}$, respectively - and slightly differ from the ones of $\mathrm{Al}_{13} \mathrm{Co}_{4}(100)(-0.24 \mathrm{eV})$. Focusing on catalytic performances, $\mathrm{Al}_{5} \mathrm{Co}_{2}(2 \overline{1} 0)$, like $\mathrm{Al}_{13} \mathrm{Co}_{4}(100)$, presents a lower activity at $383 \mathrm{~K}$ than $\mathrm{Al}_{13} \mathrm{Fe}_{4}(010)$, which is very active even at RT.

Adsorption energies are a key element of any theoretical search for new catalyst materials, the Sabatier principle setting a correlation between the catalytic activity and the catalyst/molecular interactions. Here we demonstrated that although similarities exist betweeen (i) the $\mathrm{Al}_{13} \mathrm{Fe}_{4}(010)$ and $\mathrm{Al}_{5} \mathrm{Co}_{2}(2 \overline{1} 0)$ surface structures investigated under ultra-high vacuum and (ii) their corresponding adsorption properties calculated using DFT, their catalytic performances are rather different. This different catalytic behaviour may come from kinetic factors, or from the emergence of a different surface structure under reaction conditions.

\section{Conclusion}

This work experimentally and theoretically identified the $\mathrm{Al}_{5} \mathrm{Co}_{2}(2 \overline{1} 0)$ surface as a highly selective catalyst though moderately active for the semi-hydrogenation of butadiene. The surface activity and selectivity strongly depends on the surface structure, which was determined by a combination of SXRD measurements and DFT calculations. Stable surface models differ only by the presence/absence of a low density of surface Co atoms, but their discrimination is shown to be possible, via the SXRD/DFT approach. Our analysis leads to the conclusion that surface Co atoms are well isolated from each other at the surface, their nearest-neighbor distance being $7.6 \AA$.

In addition, DFT calculations show that the density of surface Co atoms has a significant influence on the adsorption energies of butadiene and butene. Co-adsorption, pressure and temperature modify these energies. Both chemisorbed and physisorbed butene molecules are adsorbed in reaction conditions, but less strongly than butadiene. The hydrogenation leading to physisorption of butene seems more realistic when comparing to experimental results. This may also explain the hydrogenation of butene experimentally observed once butadiene is fully converted.

Our study clearly shows that although $\mathrm{Al}_{13} \mathrm{Fe}_{4}(010)$ and $\mathrm{Al}_{5} \mathrm{Co}_{2}(2 \overline{1} 0)$ present similar atomic and electronic surface structures under ultra-high vacuum, with the presence of well isolated transition metal atoms protruding at the surface, and show analogous adsorption prop- 
erties, their catalytic performances are rather different. This may originate from fine electronic/geometric details of the surface structures. Further theoretical and experimental investigations, including the determination of the surface structure under reaction condition, and of a possible reaction path, have to be conducted to fully understand the catalytic properties of $\mathrm{Al}_{5} \mathrm{Co}_{2}(2 \overline{1} 0)$.

Acknowledgement C.C. acknowledges Synchrotron SOLEIL and Région Grand Est for financial support. The authors thank Benjamin Voisin for technical support thoughout the SXRD experiments and Dr. Michèle Sauvage-Simkin for fruitful discussions. This work is supported by the European Integrated Center for the Development of New Metallic Alloys and Compounds. Some of us acknowledge financial support through the COMETE project (COnception in silico de Matériaux pour l'EnvironnemenT et l'Énergie) co-funded by the European Union under the program FEDER-FSE Lorraine et Massif des Vosges 2014-2020. High Performance Computing resources were provided by GENCI under the allocation 99642, as well as the EXPLOR center hosted by the Université de Lorraine (allocation 2017M4XXX0108).

\section{Supporting Information Available}

AES spectra, LEED pattern, Theoretical details and adsorption results.

\section{References}

1. Vignola, E.; Steinmann, S. N.; Vandegehuchte, B. D.; Curulla, D.; Sautet, P. $\mathrm{C}_{2} \mathrm{H}_{2}$ Induced Surface Restructuring of Pd-Ag Catalysts: Insights From Theoretical Modeling. J. Phys. Chem. C 2016, 120, 26320-26327.

2. Piccolo, L.; Piednoir, A.; Bertolini, J. Pd-Au Single-Crystal Surfaces: Segregation Properties and Catalytic Activity in the Selective Hydrogenation of 1,3-Butadiene. Surf. Sci. 2005, 592, 169-81.

3. Hugon, A.; Delannoy, L.; Krafft, J.-M.; Louis, C. Selective Hydrogenation of 1,3-Butadiene in the Presence of an Excess of Alkenes over Supported Bimetallic Gold-Palladium Catalysts. J. Phys. Chem. C 2010, 114, 10823-10835.

4. Cooper, A.; Bachiller-Baeza, B.; Anderson, J. A.; Rodriguez-Ramos, I.; Guerrero-Ruiz, A. Design of Surface Sites for the Selective Hydrogenation of 1,3-Butadiene On Pd Nanoparticles: Cu Bimetallic Formation and Sulfur Poisoning. Catal. Sci. Technol. 2014, 4, 1446-55.

5. Studt, F.; Abild-Pedersen, F.; Bligaard, T.; Sorensen, R. Z.; Christensen, C. H.; Norskov, J. K.
Identification of Non-Precious Metal Alloy Catalysts for Selective Hydrogenation of Acetylene. Science 2008, 320, 1320-1322.

6. Sachtler, W. M. H. Chemisorption Complexes On Alloy Surfaces. Catal. Rev. 1976, 14, 193-210.

7. Borodzinski, A.; Bond, G. C. Selective Hydrogenation of Ethyne in Ethene-Rich Streams on Palladium Catalysts, Part 2: Steady-State Kinetics and Effects of Palladium Particle Size, Carbon Monoxide, and Promoters. Catal. Rev. Sci. Eng. 2008, 50, 379-469.

8. Armbrüster, M.; Kovnir, K.; Friedrich, M.; Teschner, D.; Wowsnick, G.; Hahne, M.; Gille, P.; Szentmiklosi, L.; Feuerbacher, M.; Heggen, M. et al. $\mathrm{Al}_{13} \mathrm{Fe}_{4}$ as a Low-Cost Alternative for Palladium in Heterogeneous Hydrogenation. Nat. Mater. 2012, 11, 690-693.

9. Armbrüster, M.; Kovnir, K.; Grin, Y.; Schlögl, R.; Gille, P.; Heggen, M.; Feuerbacher, M. Ordered Cobalt-Aluminium and Iron-Aluminium Intermetallic Compounds as Hydrogenation Catalysts. European Patent 09157875.7, 2009.

10. Piccolo, L. $\mathrm{Al}_{13} \mathrm{Fe}_{4}$ Selectively Catalyzes the Hydrogenation of Butadiene At Room Temperature. Chem. Commun. 2013, 49, 9149-9151.

11. Ledieu, J.; Gaudry, E.; Loli, L. N. S.; Villaseca, S. A.; de Weerd, M.-C.; Hahne, M.; Gille, P.; Grin, Y.; Dubois, J.-M.; Fournée, V. Structural Investigation of the (010) Surface of the $\mathrm{Al}_{13} \mathrm{Fe}_{4}$ Catalyst. Phys. Rev. Lett. 2013, 110, 076102.

12. Piccolo, L.; Kibis, L. The Partial Hydrogenation of Butadiene over $\mathrm{Al}_{13} \mathrm{Fe}_{4}$ : A Surface-Science Study of Reaction and Deactivation Mechanisms. J. Catal. 2015, 332, 112.

13. Kandaskalov, D.; Fournée, V.; Ledieu, J.; Gaudry, E. Adsorption Properties of the o$\mathrm{AL}_{13} \mathrm{Co}_{4}(100)$ Surface Towards Molecules Involved in the Semi-Hydrogenation of Acetylene. J. Phys. Chem. C 2014, 118, 23032-2304.

14. Kandaskalov, D.; Fournée, V.; Ledieu, J.; Gaudry, E. Catalytic Semihydrogenation of Acetylene on the (100) Surface of the $\mathrm{o}^{-} \mathrm{Al}_{13} \mathrm{Co}_{4}$ Quasicrystalline Approximant: Density Functional Theory Study. J. Phys. Chem. C 2017, 121, 1873818745 .

15. Piccolo, L.; Chatelier, C.; de Weerd, M.-C.; Morfin, F.; Ledieu, J.; Fournée, V.; Gille, P.; Gaudry, E. Catalytic Properties of $\mathrm{Al}_{13} \mathrm{TM}_{4}$ Complex Intermetallics: Influence of the Transition Metal and the Surface Orientation On Butadiene Hydrogenation. Sci. Tech. Adv. Mater. 2019, 20, 557-567. 
16. Dubois, J.-M., Belin-Ferré, E., Eds. Complex Metallic Alloys: Fundamentals and Applications; WileyVCH: Weinheim, 2011.

17. Scheid, P.; Chatelier, C.; Ledieu, J.; Fournée, V.; Gaudry, E. Bonding Network and Stability of Clusters: The Case Study of the $\mathrm{Al}_{13} \mathrm{TM}_{4}$ Pseudo10fold Surfaces. Acta Crystallogr. A 2019, 75, 314324.

18. Furukawa, S.; Komatsu, T. Intermetallic Compounds: Promising Inorganic Materials for WellStructured and Electronically Modified Reaction Environments for Efficient Catalysis. ACS Catal. 2017, 7, 735-765.

19. Kovnir, K.; Armbruester, M.; Teschner, D.; Venkov, T.; Jentoft, F.; Knop-Gericke, A.; Grin, Y.; Schloegl, R. A New Approach To Well-Defined, Stable and Site-Isolated Catalysts. Sci. Technol. Adv. Mater. 2007, 8, 420-427.

20. Greiner, M.; Jones, T.; Beeg, S.; Zwiener, L.; Scherzer, M.; Girgsdies, F.; Piccinin, S.; Armbrüster, M.; Knop-Gericke, A.; Schlögl, R. Free-Atom-Like $D$-States in Single-Atom Alloy Catalysts. Nat. Chem. 2018, 10, 1008-1015.

21. Kitchin, J. R.; Norskov, J. K.; Barteau, M. A.; Chen, J. G. Role of Strain and Ligand Effects in the Modification of the Electronic and Chemical Properties of Bimetallic Surfaces. Phys. Rev. Lett. 2004, 93, 156801.

22. Mavrikakis, M.; Hammer, B.; Norskov, J. K. Effect of Strain on the Reactivity of Metal Surfaces. Phys. Rev. Lett. 1998, 81, 2819-22.

23. Tsai, A. P.; Kameoka, S.; Ishii, Y. PdZn=Cu: Can an Intermetallic Compound Replace an Element? J. Phys. Soc. Jpn. 2004, 73, 3270-3273.

24. Tsai, A.; Kameoka, S.; Nozawa, K.; Shimoda, M.; Ishii, Y. Intermetallic: A Pseudoelement for Catalysis. Acc. Chem. Res. 2017, 50, 2879-2885.

25. Hammer, B. Bond Activation at Monatomic Steps: NO Dissociation at Corrugated $\mathrm{Ru}(0001)$. Phys. Rev. Lett. 1999, 83, 3681-3684.

26. Meier, M.; Ledieu, J.; Weerd, M.-C. D.; Fournée, V.; Gaudry, E. Structural Investigations of $\mathrm{Al}_{5} \mathrm{Co}_{2}(2 \overline{1} 0)$ and (100) Surfaces: Influence of Bonding Strength and Annealing Temperature On Surface Terminations. Phys. Rev. B 2016, 93,075412 (1to11).

27. Meier, M.; Ledieu, J.; Fournée, V.; Gaudry, E. Semi-Hydrogenation of Acetylene On $\mathrm{Al}_{5} \mathrm{Co}_{2}$ Surfaces. J. Phys. Chem. C 2017, 121, 4958-4969.
28. Gaudry, E.; Chatelier, C.; McGuirk, G.; Loli, L. S.; DeWeerd, M.-C.; Ledieu, J.; Fournée, V.; Felici, R.; Drnec, J.; Beutier, G. et al. Structure of the $\mathrm{Al}_{13} \mathrm{Co}_{4}(100)$ Surface: Combination of Surface X-Ray Diffraction and Ab Initio Calculations. Phys. Rev. B 2016, 94, 165406.

29. Roy, S.; Mohseni, K.; Förster, S.; Trautmann, M.; Schumann, F.; Zollner, E.; Meyerheim, H.; Widdra, W. The Kepler Tiling as the Oldest Complex Surface Structure in History: X-Ray Structure Analysis of A Two-Dimensional Oxide Quasicrystal Approximant. Z. Kristallogr. - Cryst. Mater 2016, 231, 749-755.

30. Meier, M.; Ledieu, J.; Weerd, M.-C. D.; Huang, Y.T.; Abreu, G. J. P.; Diehl, R.; Mazet, T.; Vincent.Fournée,; Gaudry, E. Interplay Between Bulk Atomic Clusters and Surface Structure in Complex Intermetallic Compounds: the Case Study of the $\mathrm{Al}_{5} \mathrm{Co}_{2}(001)$ Surface. Phys. Rev. B 2015, 91, 085414 (1to16).

31. Morfin, F.; Piccolo, L. A Versatile ElevatedPressure Reactor Combined With an Ultrahigh Vacuum Surface Setup for Efficient Testing of Model and Powder Catalysts Under Clean GasPhase Conditions. Rev. Sci. Instrum. 2013, 84, 094101.

32. Vlieg, E. Integrated Intensities Using A Six-Circle Surface X-Ray Diffractometer. J. Appl. Cryst 1997, $30,532-543$.

33. Robach, O.; Garreau, Y.; Aïd, K.; VéronJolliot, M. B. Corrections for Surface X-Ray Diffraction Measurements Using the Z-Axis Geometry: Finite Size Effects in Direct and Reciprocal Space. J. Appl. Cryst. 2000, 33, 1006-1018.

34. Drnec, J.; Zhou, T.; Pintea, S.; Onderwaater, W.; Vlieg, E.; Renaud, G.; Felici, R. Integration Techniques for Surface X-Ray Diffraction Data Obtained With A Two-Dimensional Detector. J. Appl. Cryst. 2014, 47, 365-377.

35. Roobol, S.; Onderwater, W.; Drnec, J.; Felici, R.; Frenken, J. BINoculars : Data Reduction and Analysis Software for Two-Dimensional Detectors in Surface X-Ray Diffraction. J. Appl. Cryst. 2015, 48, 1324-1329.

36. Vlieg, E. ROD: A Program for Surface X-Ray Crystallography. J. Appl. Cryst 2000, 33, 401-405.

37. Kresse, G.; Hafner, J. Ab Initio Molecular Dynamics for Liquid Metals. Phys. Rev. B 1993, 47, 558561. 
38. Kresse, G.; Hafner, J. Ab Initio MolecularDynamics Simulation of the Liquid-MetalAmorphous-Semiconductor Transition in Germanium. Phys. Rev. B 1994, 49, 14251-14269.

39. Kresse, G.; Furthmüller, J. Efficient Iterative Schemes for Ab Initio Total-Energy Calculations Using A Plane-Wave Basis Set. Phys. Rev. B 1996, $54,11169-11186$.

40. Kresse, G.; Furthmüller, J. Efficiency of Ab-Initio Total Energy Calculations For metals and semiconductors using a plane wave basis set. Comput. Mater. Sci. 1996, 6, 15-50.

41. Blochl, P. E. Projector Augmented-Wave Method. Phys. Rev. B 1994, 50, 17953-17979.

42. Kresse, G.; Joubert, D. From Ultrasoft Pseudopotentials To the Projector Augmented-Wave Method. Phys. Rev. B 1999, 59, 1758-1775.

43. Perdew, J. P.; Burke, K.; Ernzerhof, M. Generalized Gradient Approximation Made Simple. Phys. Rev. Lett. 1996, r7, 3865.

44. Perdew, J. P.; Burke, K.; Ernzerhof, M. Erratum: Generalized Gradient Approximation Made Simple. Phys. Rev. Lett. 1997, 78, 1396.

45. Mihalkovič, M.; Widom, M. First-Principles Calculations of Cohesive Energies In the Al-Co Binary Alloy System. Phys. Rev. B 2007, 75, 014207.

46. Shin, H.; Pussi, K.; Gaudry, É.; Ledieu, J.; Fournée, V.; Alarcón-Villaseca, S.; Dubois, J.-M.; Grin, Y.; Gille, P.; Moritz, W. et al. Structure of the Orthorhombic $\mathrm{Al}_{13} \mathrm{Co}_{4}(100)$ Surface Using LEED, STM and Ab Initio Studies. Phys. Rev. B 2011, 84, 085411 (1to11).

47. Momma, K.; Izumi, F. VESTA 3 for ThreeDimensional Visualization of Crystal, Volumetric and Morphology Data. J. Appl. Crystallogr. 2011, 44, 1272-1276.

48. Grimme, S.; Ehrlich, S.; Goerigk, L. Effect of The Damping Function in Dispersion Corrected Density Functional Theory. J. Comput. Chem. 2011, 32, 1456.

49. Goerigk, L. Non-covalent Interactions in Quantum Chemistry and Physics: Theory and Applications, A. Otero de la Roza and G. A. Di Labio ed.; Elsevier: Amsterdam, 2017; Chapter A Comprehensive Overview of the DFT-D3 London-Dispersion Correction.

50. Cooper, A. S. Precise Lattice Constants of Germanium, Aluminum, Gallium Arsenide, Uranium, Sulphur, Quartz and Sapphire. Acta Crystallogr. 1962, $15,578-582$.
51. Hofer, L. J. E.; Peebles, W. C. Preparation and XRay Diffraction Studies of A New Cobalt Carbide. J. Am. Chem. Soc. 1947, 69, 893-899.

52. Kittel, C. Introduction to Solid State Physics, 7th ed.; John Wiley \& Sons: USA, 1996.

53. Burkhardt, U.; Ellner, M.; Grin, Y.; Baumgartner, B. Powder Diffraction Refinement of the $\mathrm{Co}_{2} \mathrm{Al}_{5}$ Structure. Powder Diffr. 1998, 13, 159162.

54. Widom, M.; Moriarty, J. A. First-Principles Interatomic Potentials for Transition-Metal Aluminides. II. Application To Al-Co and Al-Ni Phase Diagrams. Phys. Rev. B 1998, 58, 8967-8979.

55. Tersoff, J.; Hamann, D. R. Theory and Application for the Scanning Tunneling Microscope. Phys. Rev. Lett. 1983, 50, 1998-2001.

56. Tersoff, J.; Hamann, D. R. Theory of The Scanning Tunneling Microscope. Phys. Rev. B 1985, 31, 805813.

57. Vigne, F.; Haubrich, J.; Loffreda, D.; Sautet, P.; F. Delbecq, F. Highly Selective Hydrogenation of Butadiene On Pt/Sn Alloy Elucidated By FirstPrinciples Calculations. J. Catal. 2010, 275, 129139.

58. Gwyer, A. G. C. Über die Legierungen des Aluminiums mit Kupfer, Eisen, Nickel, Kobalt, Blei und Cadmium. Z. Anorg. Chem. 1908, 57, 113-153.

59. Bradley, A.; Cheng, C. S. The Crystal Structure of $\mathrm{Co}_{2} \mathrm{Al}_{5}$. Zeit. Kri. - Cryst. Mat. 1938, 99, 480-487.

60. Ormeci, A.; Grin, Y. Chemical Bonding in $\mathrm{Al}_{5} \mathrm{Co}_{2}$ : the Electron Localizability - Electron Density Approach. Israel Journal of Chemistry 2011, 51, 1349.

61. Kitchin, J.; Reuter, K.; Scheffler, M. Alloy Surface Segregation in Reactive Environments: FirstPrinciples Atomistic Thermodynamics Study of $\mathrm{Ag}_{3} \mathrm{Pd}(111)$ in Oxygen Atmospheres. Phys. Rev. B 2008, 77, 075437.

62. Blum, V.; hammer, L.; Schmidt, C.; Wieckhorst, O.; Müller, S.; Heinz, K. Segregation in Strongly Ordering Compounds: A Key Role of Constitutional Defects. Phys. Rev. Lett. 2002, 89, 266102.

63. Villars, P.; Calvert, L. D. Pearson's Handbook of Crystallographic Data for Intermetallic Phases; ASM International: Metals Park, Ohio, USA, 1998.

64. Krajčí, M.; Hafner, J. Complex Intermetallic Compounds as Selective Hydrogenation Catalysts - A Case Study for the (100) Surface of $\mathrm{Al}_{13} \mathrm{Co}_{4} . J$. Catal. 2011, 278, 200-207. 
65. Krajčí, M.; Hafner, J. Intermetallic Compound AlPd as a Selective Hydrogenation Catalyst: A DFT Study. J. Phys. Chem. C 2012, 116, 63076319 .

66. Krajčí, M.; Hafner, J. The (210) Surface of Intermetallic B20 Compound GaPd as A Selective Hydrogenation Catalyst: A DFT Study. J. Catal. 2012, 295, 70-80.

67. Vajda, E.; Tremmel, J.; Rozsondai, B.; Hargittai, I.; Maltsev, A. K.; Kagramonov, N. D.; Nefedov, O. M. Molecular Structure of Allyl Radical From Electron Diffraction. J. Am. Chem. Soc 1986, 108, 43524353. 
TOC graphic

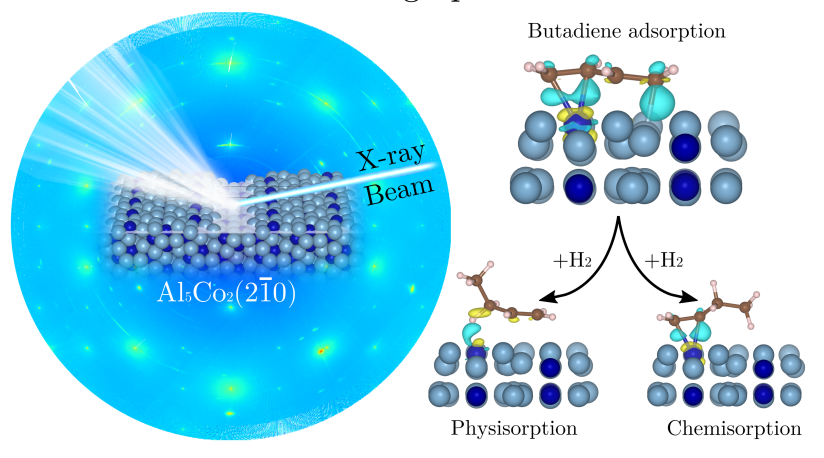




\section{From Surface Structure to Catalytic Properties}

\section{of $\mathrm{Al}_{5} \mathrm{Co}_{2}(2 \overline{10})$ : a Thorough Study Combining Experimental and Theoretical Approaches}

Corentin Chatelier ${ }^{1,2}$, Yves Garreau ${ }^{2,3}$, Laurent Piccolo ${ }^{4}$, Alina Vlad ${ }^{2}$, Andrea Resta $^{2}$, Julian Ledieu ${ }^{1}$, Vincent Fournée ${ }^{1}$, Marie-Cécile de Weerd ${ }^{1}$, Frédéric-Emmanuel Picca²,

Marc de Boissieu ${ }^{5}$, Roberto Felici ${ }^{6}$, Alessandro Coati ${ }^{*, 2}$ and Émilie Gaudry*,1

\footnotetext{
${ }^{1}$ Université de Lorraine, CNRS, Institut Jean Lamour - UMR 7198, Campus ARTEM, 2 Allée André Guinier, F-54011, Nancy, France

${ }^{2}$ Synchrotron SOLEIL, L'Orme des Merisiers Saint-Aubin, BP 48, F-91192 Gif-sur-Yvette Cedex, France

${ }^{3}$ Université de Paris, Laboratoire Matériaux et Phénomènes Quantiques, CNRS, F-75013, Paris, France

${ }^{4}$ Univ Lyon, Université Claude Bernard - Lyon 1, CNRS, IRCELYON - UMR 5256, 2 Avenue Albert Einstein, F-69626, Villeurbanne CEDEX, France

${ }^{5}$ Université Grenoble Alpes, CNRS, Science et Ingénierie des Matériaux et Procédés - UMR 5266, 1130 rue de la piscine, Domaine Universitaire, BP 75, F-38402 Saint-Martin d'Hères, France

${ }^{6}$ CNR-SPIN, Area della Ricerca di Tor Vergata, Via del Fosso del Cavaliere 100, I-00133 Roma, Italy

E-mail: alessandro.coati@synchrotron-soleil.fr,emilie.gaudry@univ-lorraine.fr
}

SUPPORTING INFO 


\section{S1 - Experimental data: LEED pattern and Auger Elec-}

\section{tron Spectra}

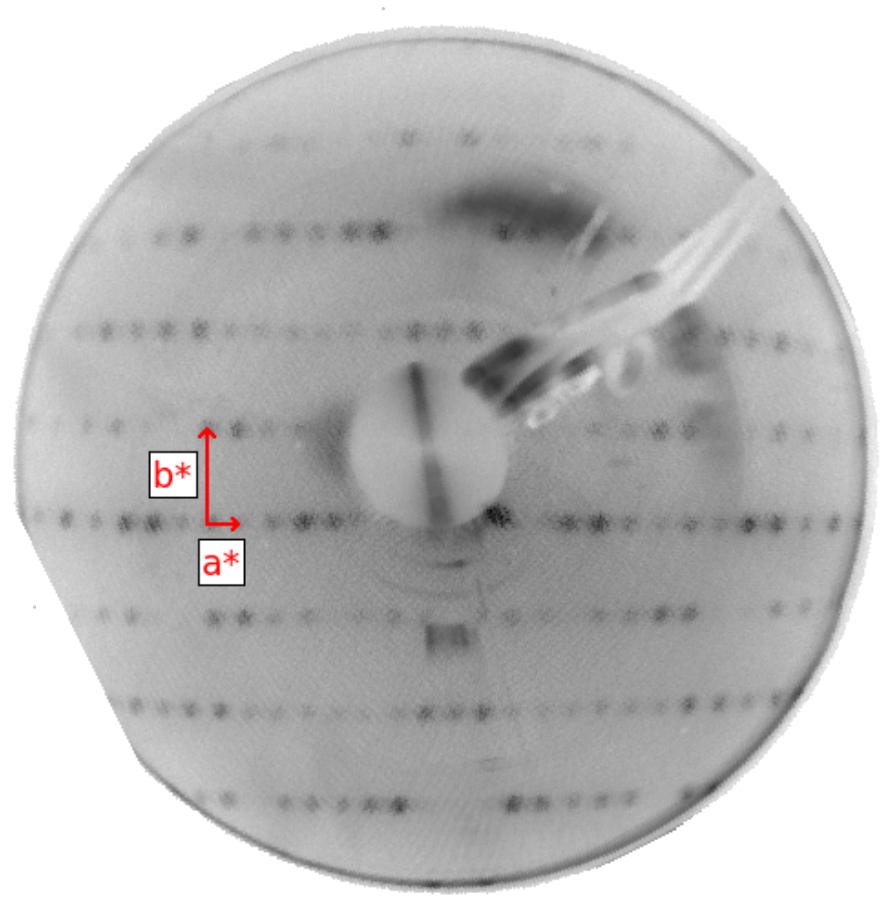

Figure S1: LEED pattern measured in the SixS UHV preparation chamber at $80 \mathrm{eV}$ showing the $(2 \times 1)$ surface reconstruction $\left(\mathbf{a}^{\star}=[120]\right.$ and $\left.\mathbf{b}^{\star}=[001]\right)$. The periodicity is doubled in the [120] direction. Cell parameters are $a=26.78 \AA$ and $b=7.63 \AA$, according to SXRD. 


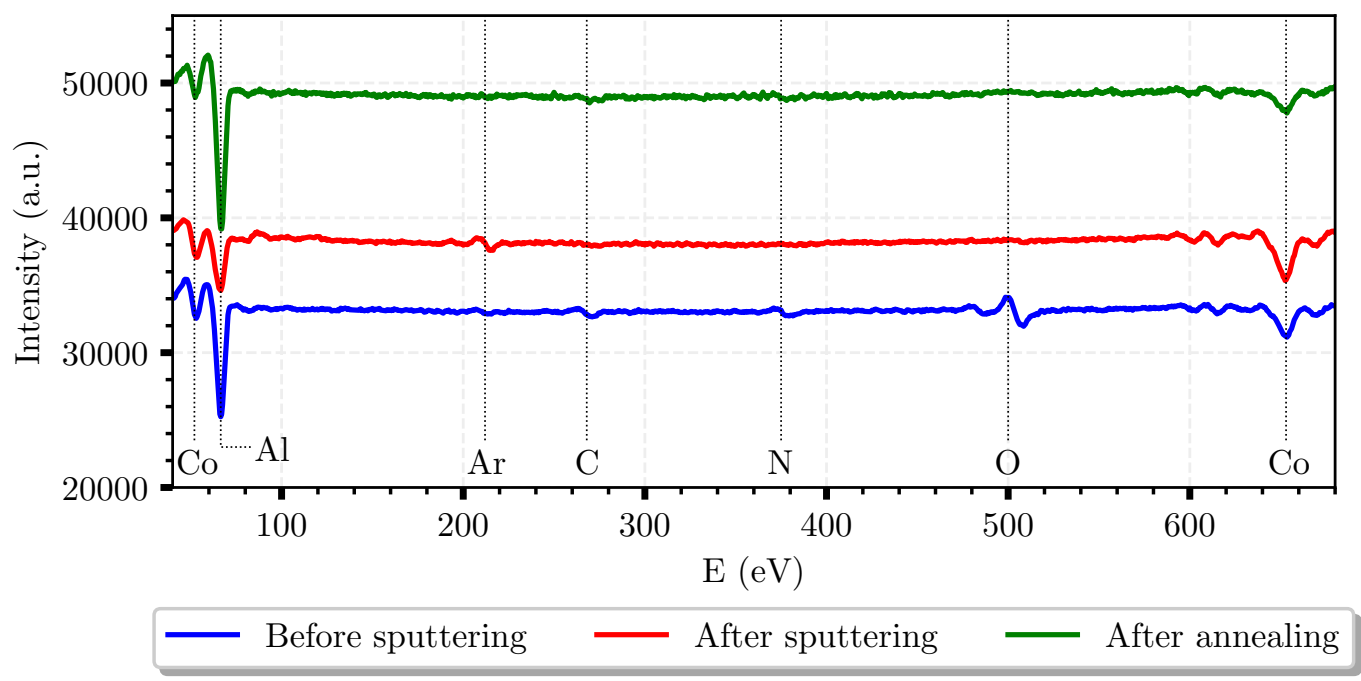

Figure S2: Auger Electron Spectra before and after $\mathrm{Ar}^{+}$sputtering (for 30 min at $1.5 \mathrm{keV}$ ) measured in the SixS UHV preparation chamber. 


\section{S2 - Computational data}

The surface energies $\gamma$ of the four surface models described previously are calculated using

$$
\gamma=\frac{1}{2 A}\left(E^{\text {slab }}-\frac{\mu_{\mathrm{Al}_{5} \mathrm{Co}_{2}}^{\text {bulk }} N_{\mathrm{Co}}^{\text {slab }}}{2}-\mu_{\mathrm{Al}}^{\text {bulk }}\left(N_{\mathrm{Al}}^{\text {slab }}-\frac{5}{2} N_{\mathrm{Co}}^{\text {slab }}\right)-\left(\mu_{\mathrm{Al}}-\mu_{\mathrm{Al}}^{\text {bulk }}\right)\left(N_{\mathrm{Al}}^{\text {slab }}-\frac{5}{2} N_{\mathrm{Co}}^{\text {slab }}\right)\right)
$$

where $A, E^{s l a b}, N_{X}^{s l a b}$ and $\mu_{\mathrm{X}}$ are the area of the surface cell, the total slab energy, the number of $\mathrm{X}$ atoms in the slab (X $=\mathrm{Al}, \mathrm{Co})$ and the corresponding chemical potentials, respectively. The chemical potential of bulk $\mathrm{Al}_{5} \mathrm{Co}_{2}\left(\mu_{\mathrm{Al}_{5} \mathrm{Co}_{2}}^{\text {bulk }}\right)$ is expressed with the $\mathrm{X}$ elemental chemical

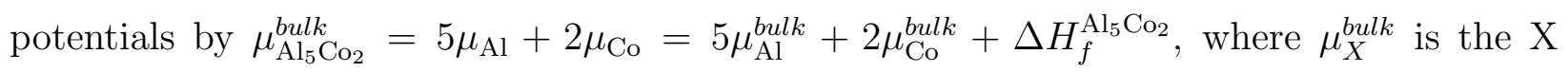
elemental cohesive energy and $\Delta H_{f}^{\mathrm{Al}_{5} \mathrm{Co}_{2}}$ is the $\mathrm{Al}_{5} \mathrm{Co}_{2}$ formation enthalpy. The latter is used to define the allowed range for the chemical potentials : $\frac{7}{5} \Delta H_{f}^{\mathrm{Al}_{5} \mathrm{Co}_{2}} \leq \mu_{\mathrm{Al}}-\mu_{\mathrm{Al}}^{b u l k} \leq 0$.

The thermodynamic model used in the paper requires the calculation of the rotational partition function. The inertia constants $\left(I_{i}\right)$ are taken from Craig et al. ${ }^{1}$ for butadiene $\left(I_{a}=2.01 \cdot 10^{-46} \mathrm{~kg} \cdot \mathrm{m}^{2}, I_{b}=1.89 \cdot 10^{-45} \mathrm{~kg} . \mathrm{m}^{2}, I_{c}=2.09 \cdot 10^{-45} \mathrm{~kg} \cdot \mathrm{m}^{2}\right)$, from Bouchy et al. ${ }^{2}$ for 1-butene $\left(I_{a}=5.54 \cdot 10^{-46} \mathrm{~kg} \cdot \mathrm{m}^{2}, I_{b}=1.54 \cdot 10^{-45} \mathrm{~kg} \cdot \mathrm{m}^{2}, I_{c}=1.99 \cdot 10^{-45} \mathrm{~kg} \cdot \mathrm{m}^{2}\right)$. For hydrogen atoms, the inertia constant is equal to $I_{H_{2}}=4.57 \cdot 10^{-48} \mathrm{~kg} \cdot \mathrm{m}^{2}$. The symmetry parameter $\sigma$ is equal to 2 .

The thermodynamic model is fed by adsorption energies. Tables S1, S2 and S3 contain the calculated adsorption energies and geometries for $\mathrm{C}_{4} \mathrm{H}_{6}$ and $\mathrm{C}_{4} \mathrm{H}_{8}$, also shown in Fig. S3. Charge deformations are highlighted in Figs. S5, S6 and S7.

The labels were chosen to be consistent with our previous work ${ }^{3}$ based on the $\mathrm{P}_{B}$ model. The nomenclature was kept identical when considering the $\mathrm{P}_{B-2 C o}$ model. However, since two protruding Co atoms are missing using $\mathrm{P}_{B-2 C o}$ compared with $\mathrm{P}_{B}$, sites 2 and 9 do not exist any more. In addition, in our previous work, sites 3 and 7 were determined to be rather close in distance. It is the same with sites 4 and 8 . Only sites 3 and 4 were thus considered for the hydrogenated surface.

For co-adsorption studies, hydrogen adsorption sites are selected amongst the one pre- 
sented in Fig. 8 (main document) following their relative adsorption energies, i.e. for $\theta_{H}=2$, $i \in(1,3)$; for $\theta_{H}=4, i \in(1,3,4)$; for $\theta_{H}=6, i \in(1,3,4,5,6)$; for $\theta_{H}=8, i \in(1,3,4,5,6)$; for $\theta_{H}=10, i \in(1,3,4,5,6,10,11)$ and for $\theta_{H}=12, i \in(1,3,4,5,6,10,11)$. Resulting co-adsorption energies are gathered in Tabs. S4 and S5, and shown in Fig. S4.

Table S1: Trans-1,3-butadiene $\left(\mathrm{C}_{4} \mathrm{H}_{6}\right)$ and 1-butene $\left(\mathrm{C}_{4} \mathrm{H}_{8}\right)$ adsorption energies on the four surface models $\left(\mathrm{P}_{\mathrm{B}}, \mathrm{P}_{\mathrm{B}-2 \mathrm{Co}, 1}, \mathrm{P}_{\mathrm{B}-2 \mathrm{Co}, 2}\right.$ and $\left.\mathrm{P}_{\mathrm{B}-4 \mathrm{Co}}\right)$

\begin{tabular}{c|c|cccc}
\hline \multirow{2}{*}{ Surface model } & \multirow{2}{*}{ Molecule } & \multicolumn{5}{|c}{ Adsorption site and $\mathrm{E}_{\text {ads }}(\mathrm{eV})$} \\
& & $\mathrm{A}$ & $\mathrm{B}$ & $\mathrm{C}$ & $\mathrm{D}$ \\
\hline \multirow{2}{*}{$\mathrm{P}_{\mathrm{B}}$} & $\mathrm{C}_{4} \mathrm{H}_{6}$ & -2.26 & -1.47 & -1.42 & -1.61 \\
& $\mathrm{C}_{4} \mathrm{H}_{8}$ & -1.54 & -1.48 & -1.33 & -1.16 \\
\hline \multirow{2}{*}{$\mathrm{P}_{\mathrm{B}-2 \mathrm{Co}, 1}$} & $\mathrm{C}_{4} \mathrm{H}_{6}$ & -1.92 & -1.74 & -0.53 & -1.72 \\
& $\mathrm{C}_{4} \mathrm{H}_{8}$ & -1.52 & -1.54 & -0.51 & -1.25 \\
\hline \multirow{2}{*}{$\mathrm{P}_{\mathrm{B}-2 \mathrm{Co}, 2}$} & $\mathrm{C}_{4} \mathrm{H}_{6}$ & -1.77 & -1.72 & -1.44 & -1.60 \\
& $\mathrm{C}_{4} \mathrm{H}_{8}$ & -1.48 & -0.75 & -1.36 & -1.16 \\
\hline \multirow{2}{*}{$\mathrm{P}_{\mathrm{B}-4 \mathrm{Co}}$} & $\mathrm{C}_{4} \mathrm{H}_{6}$ & -1.61 & -2.19 & -2.27 & -1.21 \\
& $\mathrm{C}_{4} \mathrm{H}_{8}$ & -0.85 & -1.37 & -1.08 & -1.26 \\
\hline
\end{tabular}

Table S2: Interatomic distances for butadiene on $\mathrm{P}_{\mathrm{B}}, \mathrm{P}_{\mathrm{B}-2 \mathrm{Co}, 1}, \mathrm{P}_{\mathrm{B}-2 \mathrm{Co}, 2}$ and $\mathrm{P}_{\mathrm{B}-4 \mathrm{Co}}$.

\begin{tabular}{|c|c|c|c|c|c|c|c|c|c|c|c|c|}
\hline Surface & Site & $\mathrm{C}_{1}-\mathrm{C}_{2}$ & $\mathrm{C}_{2}-\mathrm{C}_{3}$ & $\mathrm{C}_{3}-\mathrm{C}_{4}$ & $\mathrm{C}_{1}$-Co & $\mathrm{C}_{2}$-Co & $\mathrm{C}_{3}$-Co & $\mathrm{C}_{4}$-Co & $\mathrm{C}_{1}-\mathrm{Al}$ & $\mathrm{C}_{2}-\mathrm{Al}$ & $\mathrm{C}_{3}-\mathrm{Al}$ & $\mathrm{C}_{4}-\mathrm{Al}$ \\
\hline trans $-1,3$ & tadiene & 1.35 & 1.45 & 1.35 & & & & & & & & \\
\hline \multirow{4}{*}{$P_{B}$} & A & 1.49 & 1.43 & 1.43 & 2.11 & 2.34 & 2.01 & 2.08 & 2.24 & 2.32 & 3.12 & 3.36 \\
\hline & B & 1.42 & 1.46 & 1.35 & 2.08 & 2.11 & 3.0 & 4.05 & 3.16 & 3.23 & 3.14 & 3.91 \\
\hline & $\mathrm{C}$ & 1.35 & 1.45 & 1.42 & 4.09 & 3.02 & 2.15 & 2.06 & 3.75 & 3.32 & 3.05 & 3.08 \\
\hline & D & 1.52 & 1.41 & 1.43 & 4.05 & 4.23 & 4.18 & 3.78 & 2.06 & 2.2 & 2.62 & 3.21 \\
\hline \multirow{4}{*}{$\mathrm{P}_{\mathrm{B}-2 \mathrm{Co}, 1}$} & A & 1.43 & 1.43 & 1.46 & 2.09 & 2.02 & 2.34 & 3.25 & 3.36 & 3.25 & 2.44 & 2.07 \\
\hline & B & 1.42 & 1.44 & 1.4 & 2.06 & 2.07 & 2.69 & 3.59 & 3.26 & 2.96 & 2.42 & 2.25 \\
\hline & C & 1.35 & 1.45 & 1.36 & 4.49 & 4.45 & 3.79 & 4.21 & 3.41 & 3.62 & 3.1 & 3.05 \\
\hline & $\mathrm{D}$ & 1.52 & 1.41 & 1.43 & 4.07 & 4.22 & 3.33 & 3.89 & 2.06 & 2.19 & 2.72 & 2.16 \\
\hline \multirow{4}{*}{$\mathrm{P}_{\mathrm{B}-2 \mathrm{Co}, 2}$} & A & 1.46 & 1.43 & 1.43 & 3.34 & 2.39 & 2.03 & 2.09 & 2.08 & 2.51 & 3.18 & 3.25 \\
\hline & B & 1.47 & 1.4 & 1.5 & 4.02 & 3.37 & 2.3 & 2.94 & 2.09 & 2.53 & 2.39 & 2.05 \\
\hline & $\mathrm{C}$ & 1.35 & 1.45 & 1.42 & 4.09 & 3.01 & 2.14 & 2.06 & 3.74 & 3.25 & 3.07 & 3.16 \\
\hline & D & 1.52 & 1.41 & 1.43 & 4.05 & 4.23 & 4.18 & 3.78 & 2.06 & 2.2 & 2.62 & 3.21 \\
\hline \multirow{4}{*}{$\mathrm{P}_{\mathrm{B}-4 \mathrm{Co}}$} & A & 1.49 & 1.39 & 1.48 & 3.76 & 3.86 & 3.85 & 4.16 & 2.09 & 2.4 & 2.4 & 2.1 \\
\hline & B & 1.47 & 1.38 & 1.49 & 4.01 & 3.91 & 4.37 & 4.14 & 2.06 & 2.57 & 2.39 & 2.05 \\
\hline & $\mathrm{C}$ & 1.49 & 1.38 & 1.48 & 3.98 & 4.07 & 4.18 & 4.12 & 2.05 & 2.43 & 2.48 & 2.06 \\
\hline & $\mathrm{D}$ & 1.54 & 1.48 & 1.35 & 4.12 & 4.13 & 4.33 & 4.46 & 2.02 & 2.06 & 2.82 & 3.64 \\
\hline
\end{tabular}


Table S3: Interatomic distances for butene on $\mathrm{P}_{\mathrm{B}}, \mathrm{P}_{\mathrm{B}-2 \mathrm{Co}, 1}, \mathrm{P}_{\mathrm{B}-2 \mathrm{Co}, 2}$ and $\mathrm{P}_{\mathrm{B}-4 \mathrm{Co}}$.

\begin{tabular}{|c|c|c|c|c|c|c|c|c|c|c|c|c|}
\hline Surface & Site & $\mathrm{C}_{1}-\mathrm{C}_{2}$ & $\mathrm{C}_{2}-\mathrm{C}_{3}$ & $\mathrm{C}_{3}-\mathrm{C}_{4}$ & $\mathrm{C}_{1}$-Co & $\mathrm{C}_{2}$-Co & $\mathrm{C}_{3}$-Co & $\mathrm{C}_{4}$ - $\mathrm{Co}$ & $\mathrm{C}_{1}-\mathrm{Al}$ & $\mathrm{C}_{2}-\mathrm{Al}$ & $\mathrm{C}_{3}-\mathrm{Al}$ & $\mathrm{C}_{4}-\mathrm{Al}$ \\
\hline \multirow{4}{*}{$\mathrm{P}_{\mathrm{B}}$} & A & 1.55 & 1.52 & 1.42 & 2.63 & 3.12 & 2.07 & 2.06 & 3.28 & 3.24 & 3.05 & 3.4 \\
\hline & B & 1.41 & 1.51 & 1.53 & 2.08 & 2.1 & 3.16 & 3.88 & 3.07 & 3.33 & 3.36 & 3.65 \\
\hline & $\mathrm{C}$ & 1.52 & 1.52 & 1.42 & 4.08 & 3.15 & 2.12 & 2.07 & 3.89 & 3.6 & 3.14 & 2.95 \\
\hline & $\mathrm{D}$ & 1.54 & 1.54 & 1.53 & 3.96 & 4.12 & 4.8 & 4.47 & 2.02 & 2.05 & 2.98 & 3.5 \\
\hline \multirow{4}{*}{$\mathrm{P}_{\mathrm{B}-2 \mathrm{Co}, 1}$} & A & 1.42 & 1.52 & 1.52 & 2.09 & 2.07 & 3.13 & 3.8 & 3.45 & 3.34 & 3.53 & 3.27 \\
\hline & B & 1.42 & 1.52 & 1.52 & 2.08 & 2.1 & 3.16 & 3.89 & 3.36 & 3.14 & 3.61 & 3.34 \\
\hline & $\mathrm{C}$ & 1.53 & 1.5 & 1.35 & 4.86 & 4.39 & 3.57 & 4.1 & 4.16 & 3.7 & 2.91 & 2.85 \\
\hline & $\mathrm{D}$ & 1.54 & 1.54 & 1.53 & 4.06 & 4.16 & 4.67 & 4.35 & 2.01 & 2.05 & 2.97 & 3.52 \\
\hline \multirow{4}{*}{$\mathrm{P}_{\mathrm{B}-2 \mathrm{Co}, 2}$} & A & 1.53 & 1.52 & 1.43 & 3.88 & 3.12 & 2.07 & 2.09 & 3.47 & 3.64 & 3.35 & 3.32 \\
\hline & B & 1.52 & 1.53 & 1.47 & 3.6 & 3.16 & 2.06 & 3.02 & 3.65 & 3.1 & 2.52 & 2.07 \\
\hline & $\mathrm{C}$ & 1.52 & 1.52 & 1.42 & 4.01 & 3.15 & 2.11 & 2.08 & 3.88 & 3.6 & 3.24 & 2.94 \\
\hline & $\mathrm{D}$ & 1.54 & 1.54 & 1.53 & 3.98 & 4.14 & 4.78 & 4.47 & 2.02 & 2.05 & 2.97 & 3.5 \\
\hline \multirow{4}{*}{$\mathrm{P}_{\mathrm{B}-4 \mathrm{Co}}$} & A & 1.54 & 1.53 & 1.53 & 3.76 & 3.78 & 4.51 & 5.19 & 2.04 & 2.07 & 2.96 & 3.53 \\
\hline & B & 1.54 & 1.53 & 1.52 & 3.93 & 3.8 & 5.22 & 4.97 & 2.01 & 2.06 & 3.13 & 3.28 \\
\hline & $\mathrm{C}$ & 1.53 & 1.53 & 1.54 & 4.83 & 4.98 & 4.03 & 4.05 & 3.17 & 3.09 & 2.04 & 2.01 \\
\hline & D & 1.54 & 1.54 & 1.53 & 4.11 & 4.13 & 4.54 & 4.26 & 2.01 & 2.03 & 2.99 & 3.55 \\
\hline
\end{tabular}

Table S4: Adsorption energy of 12 hydrogen atoms, and coadsorption energy of $\mathrm{C}_{4} \mathrm{H}_{x}$ and 12 hydrogen atoms on $\mathrm{P}_{\mathrm{B}}, \mathrm{P}_{\mathrm{B}-2 \mathrm{Co}, 1}, \mathrm{P}_{\mathrm{B}-2 \mathrm{Co}, 2}$ and $\mathrm{P}_{\mathrm{B}-4 \mathrm{Co}}$

\begin{tabular}{c|c}
\hline Surface model & $\Delta E_{a d s}^{12 \mathrm{H}}(\mathrm{eV})$ \\
\hline $\mathrm{P}_{\mathrm{B}}$ & -5.49 \\
$\mathrm{P}_{\mathrm{B}-2 \mathrm{Co}, 1}$ & -3.70 \\
$\mathrm{P}_{\mathrm{B}-2 \mathrm{Co}, 2}$ & -3.34 \\
$\mathrm{P}_{\mathrm{B}-4 \mathrm{Co}}$ & -3.00 \\
\hline
\end{tabular}

\begin{tabular}{c|cc}
\hline \multirow{2}{*}{ Surface model } & \multicolumn{2}{|c}{$\mathrm{E}_{\text {coads }}^{\text {tot }}(\mathrm{eV})$} \\
& $\mathrm{C}_{4} \mathrm{H}_{6}$ & $\mathrm{C}_{4} \mathrm{H}_{8}$ \\
\hline $\mathrm{P}_{\mathrm{B}}$ & -7.69 & -7.03 \\
$\mathrm{P}_{\mathrm{B}-2 \mathrm{Co}, 1}$ & -5.77 & -5.40 \\
$\mathrm{P}_{\mathrm{B}-2 \mathrm{Co}, 2}$ & -5.42 & -4.90 \\
$\mathrm{P}_{\mathrm{B}-4 \mathrm{Co}}$ & -5.05 & -4.23 \\
\hline
\end{tabular}

Table S5: Adsorption energy as a function of $\theta_{H}$ on $\mathrm{P}_{\mathrm{B}-2 \mathrm{Co}, 1}$.

\begin{tabular}{c|c}
\hline$\theta_{H}$ for $\mathrm{P}_{\mathrm{B}-2 \mathrm{Co}, 1}$ & $\Delta E_{a d s}^{\theta_{H}}(\mathrm{eV})$ \\
\hline $2 \mathrm{H}$ & -0.92 \\
$4 \mathrm{H}$ & -1.68 \\
$6 \mathrm{H}$ & -2.37 \\
$8 \mathrm{H}$ & -2.92 \\
$10 \mathrm{H}$ & -3.29 \\
$12 \mathrm{H}$ & -3.70 \\
\hline
\end{tabular}



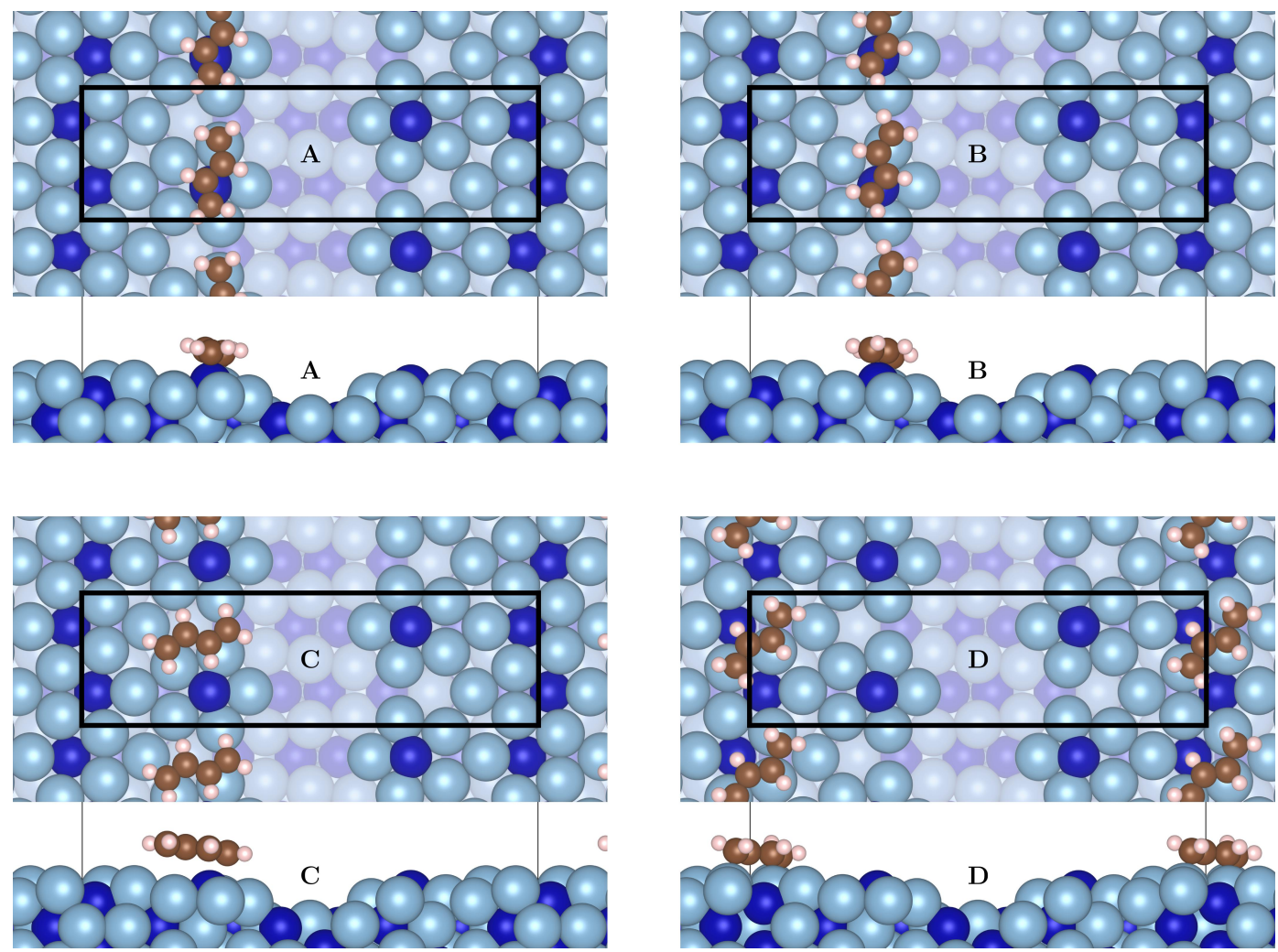

(a)
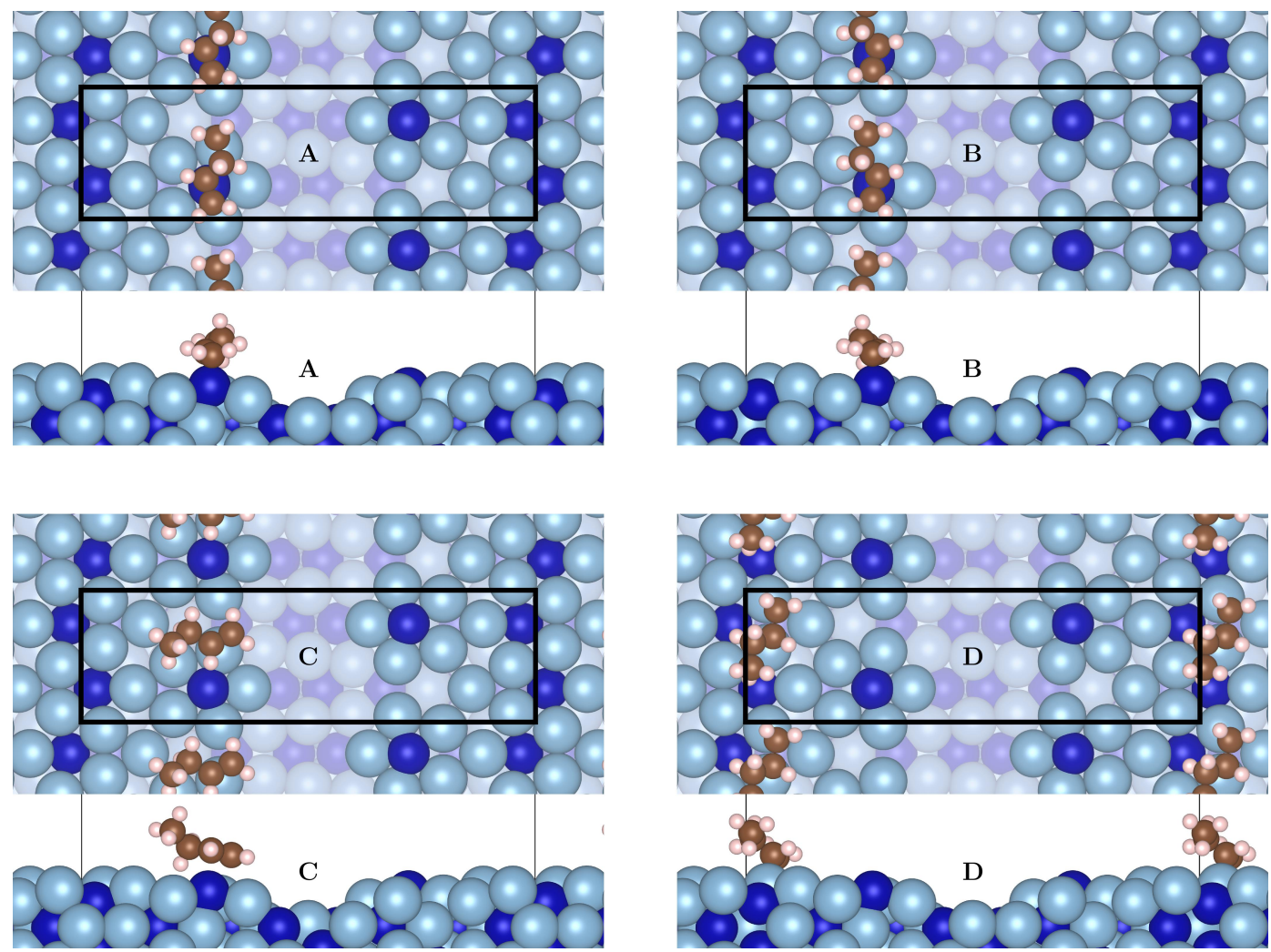

(b)

Figure S3: Adsorption sites and geometries fof (a) trans-1,3-butadiene and (b) 1-butene on $\mathrm{P}_{\mathrm{B}-2 \mathrm{Co}, 1}$. The surface unit cell is drawn in black. $\mathrm{Al}$ and Co atoms are respectively drawn in light blue and dark blue, while $\mathrm{C}$ and $\mathrm{H}$ atoms are drawn in brown and white, respectively. 

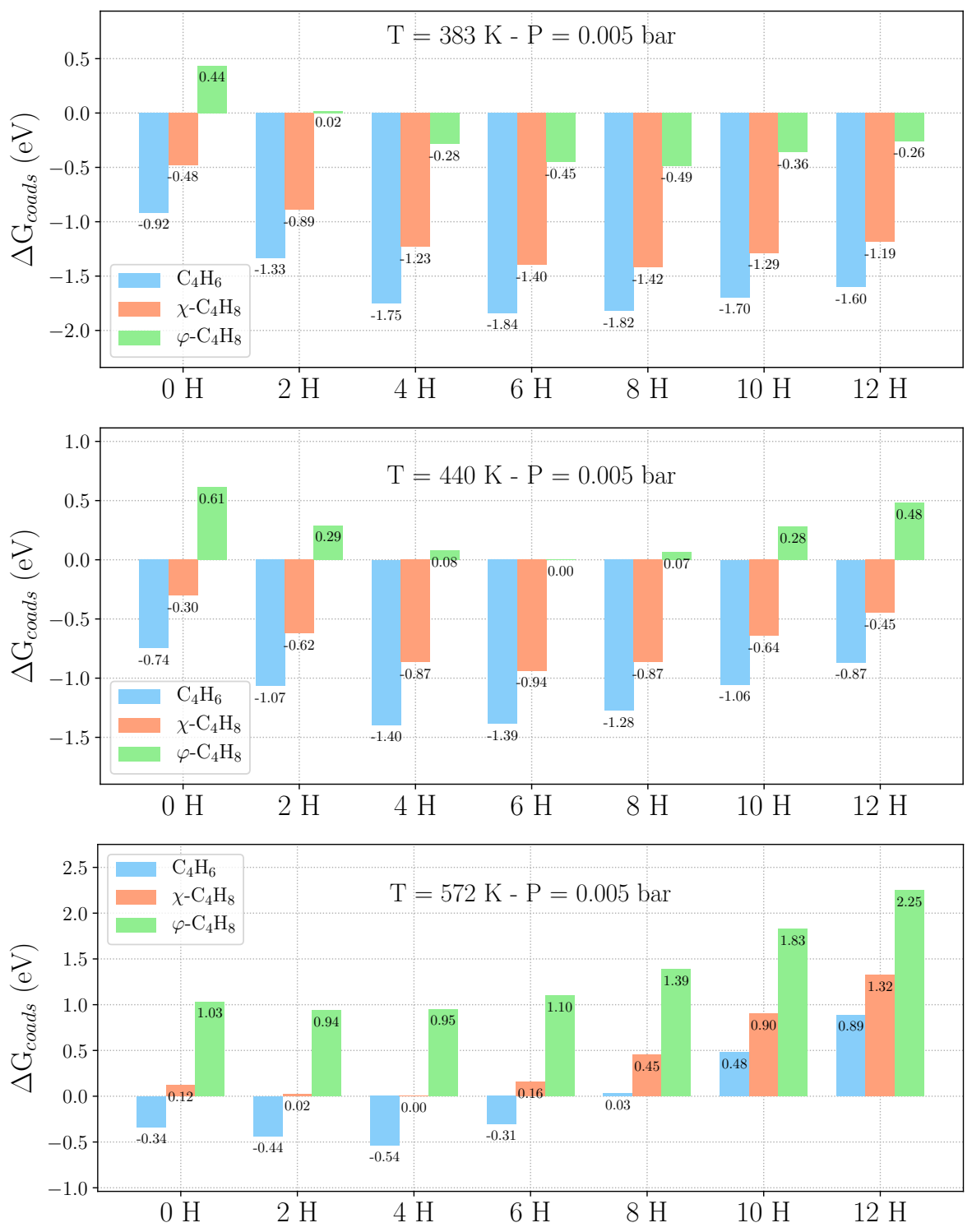

Figure S4: Co-adsorption enthalpies of hydrogen atoms, butadiene and butene plotted for $\mathrm{P}_{\mathrm{B}-2 \mathrm{Co}, 1}$ model, under the following reaction conditions: $\mathrm{p}=5.5 \mathrm{mbar}, \mathrm{T}=383 \mathrm{~K}, 440 \mathrm{~K}$ or $572 \mathrm{~K}$. 


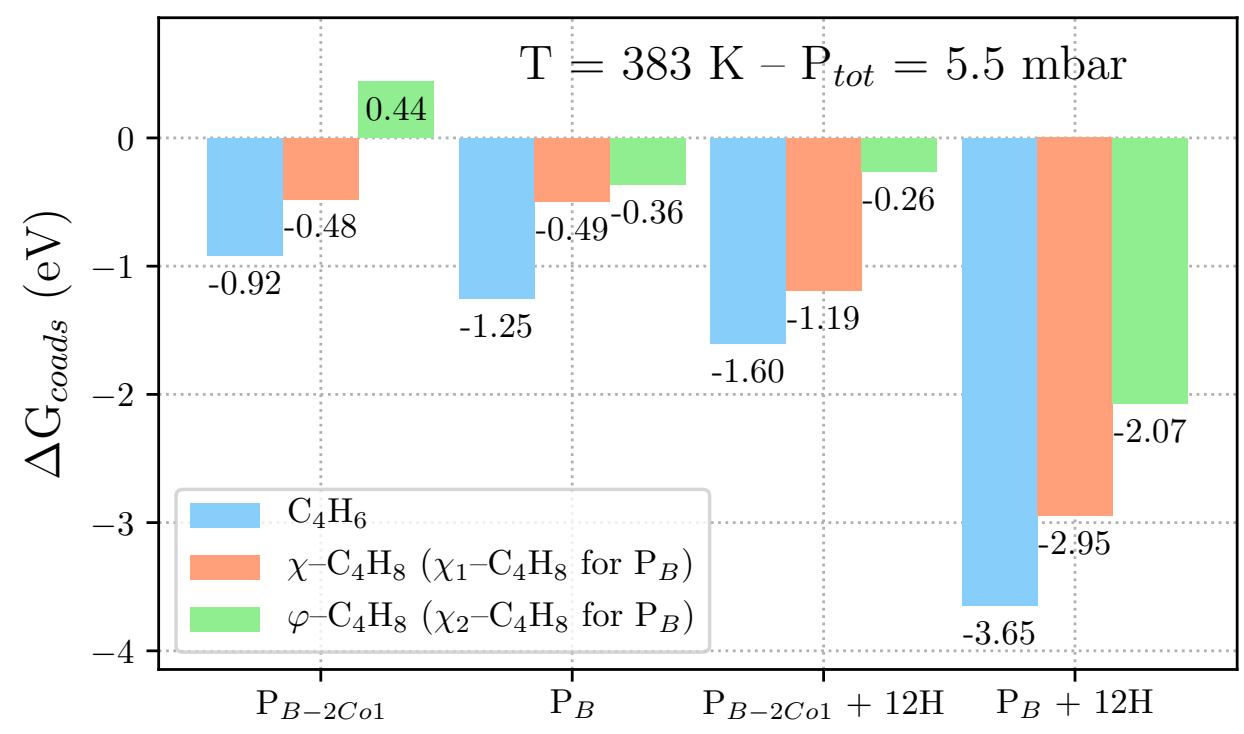

Figure S5: Coadsorption energies of hydrogen and $\mathrm{C}_{4} \mathrm{H}_{x}$ as a function of the surface model. 


\section{References}

1. Craig, N. C.; Groner, P.; McKean, D. C. Equilibrium Structures for Butadiene and Ethylene: Compelling Evidence for Pi-Electron Delocalization in Butadiene. J. Phys. Chem. A 2006, 110, 7461-7469.

2. Bouchy, A.; Roussy, G.; Ledoux, M.; Gault, F. Interpretation of the rotational spectra of multideuteriated species of but-l-ene for the study of catalytic mechanisms by microwave spectroscopy. J. de Chim. Physique 1979, 76, 357-363.

3. Meier, M.; Ledieu, J.; Fournée, V.; Gaudry, E. Semi-Hydrogenation of Acetylene On $\mathrm{Al}_{5} \mathrm{Co}_{2}$ Surfaces. J. Phys. Chem. C 2017, 121, 4958-4969. 